
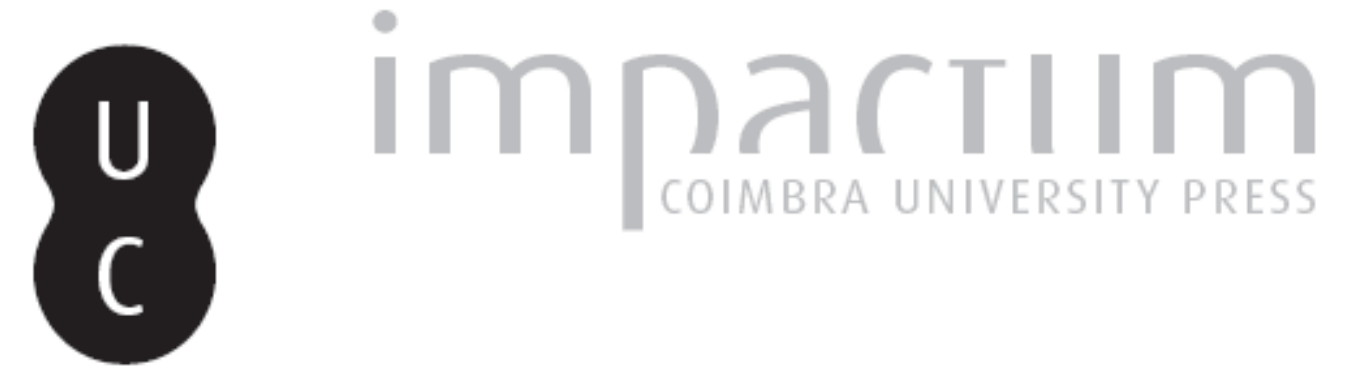

\title{
A revisão e a bonificação da incapacidade por acidente de trabalho
}

\section{Autor(es): $\quad$ Cardoso, Maria Beatriz}

Publicado por: Imprensa da Universidade de Coimbra

URL persistente:

URl:http://hdl.handle.net/10316.2/42162

DOI:

DOI:http://dx.doi.org/10.14195/1647-8630_26_6

Accessed : $\quad$ 26-Apr-2023 13:27:37

A navegação consulta e descarregamento dos títulos inseridos nas Bibliotecas Digitais UC Digitalis, UC Pombalina e UC Impactum, pressupõem a aceitação plena e sem reservas dos Termos e Condições de Uso destas Bibliotecas Digitais, disponíveis em https://digitalis.uc.pt/pt-pt/termos.

Conforme exposto nos referidos Termos e Condições de Uso, o descarregamento de títulos de acesso restrito requer uma licença válida de autorização devendo o utilizador aceder ao(s) documento(s) a partir de um endereço de IP da instituição detentora da supramencionada licença.

Ao utilizador é apenas permitido o descarregamento para uso pessoal, pelo que o emprego do(s) título(s) descarregado(s) para outro fim, designadamente comercial, carece de autorização do respetivo autor ou editor da obra.

Na medida em que todas as obras da UC Digitalis se encontram protegidas pelo Código do Direito de Autor e Direitos Conexos e demais legislação aplicável, toda a cópia, parcial ou total, deste documento, nos casos em que é legalmente admitida, deverá conter ou fazer-se acompanhar por este aviso.

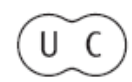




\title{
A revisão e a bonificação da incapacidade por acidente de trabalho
}

\author{
Maria Beatriz Cardoso ${ }^{1}$
}

Resumo: A revisão e a bonificação da incapacidade por acidente de trabalho. 0 presente texto faz uma abordagem crítica do regime legal da revisão e da bonificação da incapacidade por acidente de trabalho, bem como da jurisprudência existente em torno de tais matérias.

No âmbito do instituto da revisão da incapacidade, destaca-se a problemática da abolição do prazo para o efeito e da sua aplicação retroativa, fazendo-se ainda menção das situações de cura sem incapacidade, concretamente da criticidade acrescida que assume a não sujeição da revisão a qualquer prazo e o facto de a admissibilidade da mesma depender de quem é o responsável pela reparação do acidente.

É destacada a importância da avaliação concreta da incapacidade e a redundância que resulta da bonificação automática da mesma por virtude da idade igual ou superior a cinquenta anos, comprometendo a justiça da reparação do acidente de trabalho.

Finalmente, analisa-se a aplicação do fator de bonificação no âmbito da revisão da incapacidade, apontando-se a necessidade de reflexão sobre a aplicação conjugada destes dois institutos jurídicos.

Palavras-chave: Revisão; incapacidade; prazo; fator; bonificação.

Summary: The review and the allowance of disabiliy for work accident.

This paper gives a critical approach to the statutory regime corresponding to both review of disability for accident at work and its automatic allowance, as well as the existing case law related with such matters.

Within the review of disability institute, the issue of abolition of time limit for such purpose and its retroactive application are both emphasised. Reference is also made to healing situations without disability, more precisely the increased criticality witch assumes the abolition of review term and the fact that the admissibility of this revision depends on who is responsible for the repair of the accident.

1 Direção de Negócio de Acidentes de Trabalho e Pessoais; Gabinete de Contencioso e Assessoria Jurídica - Fidelidade 
It also highlights the importance of practical assessment of the disability and the redundancy that results from its automatic allowance based on the age of fifty or older, compromising the fairness of the work accident compensation.

Finally, the bonus factor is analysed in the context of disability review, pointing out the need for reflection about the combined application of these two legal institutes.

Key-words: Review; disability; term; factor; allowance.

\section{0 incidente de revisão da incapacidade}

\section{a. Evolução histórica e atual enquadramento legal}

Após a fixação judicial da incapacidade resultante de um acidente de trabalho, a mesma pode ser objeto de modificação, por via do incidente de revisão da incapacidade.

A situação incapacitante do sinistrado pode agravar-se ou, ao invés, melhorar, pelo que a valoração da incapacidade e a respetiva reparação devem refletir essas alterações.

Um sistema de reparação dos acidentes de trabalho que se pretende justo considera, necessariamente, tais vicissitudes, desiderato que há muito é salientado pela doutrina nacional. Carlos Alegre refere, a este propósito, que "O instituto da revisão das prestações é o resultado da verificação prática de muitas situações em que o estado de saúde do sinistrado, como consequência do acidente, evolui, quer no sentido do agravamento, quer no da melhoria, modificando-se, por isso, a sua capacidade de ganho ${ }^{2}$.»

Na doutrina estrangeira, o assunto também foi tratado; destacamos Miguel Hernainz Marquez, segundo o qual, embora as incapacidades permanentes tenham, por essência e denominação, um caráter de inamobilidade, não deve descartar-se a possibilidade de modificação. Enuncia como causas possíveis da mesma o erro de diagnóstico, a verificação de circunstâncias condicionais em que a avaliação se fundava, a melhoria, o agravamento e, também, a readaptação, concluindo: "Por todo ello, y ante la innegable realidade que suministran los hechos, há de marcarse un camino legal que permita dar un cauce y estado jurídico a una situación ya consagrada en la práctica. ${ }^{3}$ "

A primeira lei nacional sobre acidentes de trabalho, Lei n. ${ }^{\circ} 83$, de 24/07/1913, não previa a revisão da incapacidade; essa possibilidade surgiu

2 In Acidentes de Trabalho e Doenças Profissionais, 2a edição, Almedina, 2000, p. 125.

3 In Accidentes del Trabajo y Enfermedades Profesionales, Segunda Edicion, Madrid, 1953, p. 201. 
em 1918, com o Decreto n. 4288 , de 22/05, intitulado "Regulamento da lei dos desastres no trabalho", visando clarificar o alcance e reforçar os direitos e garantias conferidos por aquela lei aos sinistrados.

Assim, o art. ${ }^{\circ} 33 .^{\circ}$ deste diploma dispôs que «Qualquer interessado poderá requerer ao competente Tribunal de Desastres no Trabalho a revisão da pensão e da indemnização estabelecida, alegando modificação na capacidade de trabalho do sinistrado, ainda mesmo no caso da incapacidade deste ter sido julgada permanente e absoluta.».

Esta norma não previa qualquer prazo para o exercício do correspondente direito.

Na legislação que lhe sucedeu, Lei n. ${ }^{\circ} 1942$, de 27/07/1936, o art. $^{\circ} 24$. $^{\circ}$ veio introduzir um prazo para o pedido de revisão: «Qualquer interessado pode requerer a revisão das pensões por incapacidade permanente, durante o prazo de 5 anos a contar da data da homologação do acordo ou do trânsito em julgado da sentença, alegando modificação na capacidade geral de ganho da vítima do acidente, desde que, sobre a data da fixação da pensão ou da última revisão, tenham decorrido seis meses, pelo menos.».

A Lei n. ${ }^{\circ}$ 2127, de 3/08/1965, na sua Base XXII, sob a epígrafe "Revisão das pensões”, alargou o prazo de revisão para o dobro: «1 - Quando se verifique modificação da capacidade de ganho da vítima, proveniente de agravamento, recidiva, recaída ou melhoria da lesão ou da doença que deu origem à reparação, ou quando se verifique aplicação de prótese ou ortopedia, as prestações poderão ser revistas e aumentadas, reduzidas ou extintas, de harmonia com a alteração verificada. 2 - A revisão só poderá ser requerida dentro dos dez anos posteriores à data da fixação da pensão e poderá ser requerida uma vez em cada semestre, nos dois primeiros anos, e uma vez por ano, nos anos imediatos.»

A Lei n..$^{\circ}$ 100/97, de 13/09, no artigo $25 .^{\circ}$, manteve o mesmo regime da anterior, acrescentando o fundamento da reconversão profissional ${ }^{4}$ : «1 - Quando se verifique modificação da capacidade de ganho do sinistrado proveniente de agravamento, recidiva, recaída ou melhoria da lesão ou doença que deu origem à reparação, ou de intervenção clínica ou aplicação de prótese ou ortótese, ou ainda de formação ou reconversão profissional, as prestações poderão ser revistas e aumentadas, reduzidas ou extintas, de harmonia com a alteração verificada. 2 - A revisão só poderá ser requerida dentro dos 10 anos posteriores à data da fixação da pensão, uma vez em cada semestre, nos dois primeiros anos, e uma vez por ano, nos anos imediatos.»

4 Passou, pois, a contemplar-se um novo género de fundamento de revisão da incapacidade, não relacionado com a situação clínica do sinistrado, mas que pode influir decisivamente na sua capacidade de trabalho ou de ganho. 
Finalmente, a lei atualmente em vigor, Lei n. 98/2009, de 4/09, no seu art. ${ }^{\circ} 70^{\circ}$, substituiu a referência a «formação ou reconversão profissional» por «reabilitação e reintegração profissional e readaptação do posto de trabalho», numa atualização do texto em consonância com as inovações que introduziu em matéria de reabilitação e reintegração profissional.

Adicionalmente, deixou de prever qualquer prazo para o requerimento de revisão da incapacidade: «1 - Quando se verifique uma modificação na capacidade de trabalho ou de ganho do sinistrado proveniente de agravamento, recidiva, recaída ou melhoria da lesão ou doença que deu origem à reparação, ou de intervenção clínica ou aplicação de ajudas técnicas e outros dispositivos técnicos de compensação das limitações funcionais ou ainda de reabilitação e reintegração profissional e readaptação ao trabalho, a prestação pode ser alterada ou extinta, de harmonia com a modificação verificada. 2 - A revisão pode ser efectuada a requerimento do sinistrado ou do responsável pelo pagamento. 3 - A revisão pode ser requerida uma vez em cada ano civil.»

A revisão da pensão ${ }^{5}$ reveste a natureza jurídica de cato modificativo da pensão anteriormente fixada ${ }^{6}$. Vitor Ribeiro afirmava, ainda na vigência da Lei 2127, que "A revisão não envolve a "fixação" de uma nova pensão, mas a mera modificação da que já havia sido anteriormente fixada. Daí que, em princípio, se the apliquem os mesmos parâmetros de cálculo da anterior, designadamente o salário mínimo nacional utilizado para o cálculo inicial, em aplicação do art. $^{\circ} 50 .^{\circ}$ do Dec. 360/717.»

Quando tiver sido atribuída ao sinistrado uma pensão obrigatoriamente remível e, consequentemente, pago o capital da remição, se ocorrer aumento da pensão no quadro de um incidente de revisão, a pensão devida deve corresponder à diferença entre o valor inicial da pensão remida e o valor da pensão correspondente à incapacidade que resulta da revisão ${ }^{8}$.

De salientar que, se tiver havido remição da pensão, ocorrendo melhoria das lesões, com a inerente diminuição da incapacidade, não pode o responsável pedir revisão da mesma, face ao disposto na al. b) do art. ${ }^{\circ} 77 .^{\circ}$ da $\mathrm{LAT}^{9}$, que

5 Embora as sucessivas legislações empreguem a expressão revisão da pensão e, mais recentemente, revisão das prestações, é essencialmente de uma revisão da incapacidade que se trata, sendo a alteração da pensão e das demais prestações mera decorrência daquela.

6 Cfr. Ac. do STJ de 24/11/2004, Proc. ${ }^{\circ} 04$ S2171.

RIBEIRO, VITOR, in Acidentes de trabalho e doenças profissionais, Petrony, 1984, p. 37.

8 Cfr. Ac. do TR Coimbra de 17/01/2013, Proc. ${ }^{0}$ 67/09.6TTOAZ.1.C1.

9 «A remição não prejudica o direito de o sinistrado requerer a revisão da prestação.» (destaque nosso) 
reserva o pedido de revisão para o sinistrado. ${ }^{10}$. Se a iniciativa da revisão for deste, vindo a resultar uma redução da IPP, o responsável não pode pedir a devolução da diferença entre o valor pago a título de remição da pensão anual e vitalícia e o valor que seria devido pela nova incapacidade, porquanto se entende que a pensão sofre ope legis uma novação objetiva ${ }^{11}$, que a converte numa prestação unitária de certo montante ${ }^{12}$.

A lei substantiva aplicável à nova pensão é a que vigorava à data do acidente de trabalho ${ }^{13}$.

Por seu turno, a alteração das prestações opera, por norma, na data de entrada do requerimento de revisão14.

A tramitação processual do incidente de revisão da incapacidade encontra-se regulada nos art. ${ }^{\circ}{ }^{145} .^{\circ}$ e $146 .^{\circ}$ do CPT. A fundamentação do requerimento basta-se com a menção de que a incapacidade ou as lesões se agravaram (ou diminuíram, se é apresentado pelo responsável civil) ${ }^{15}$.

O pedido de revisão é processado por apenso ao processo principal, no qual foi fixada a incapacidade inicial, sendo o sinistrado submetido a exame médico singular e havendo lugar a perícia colegial mediante requerimento, caso alguma das partes não se conforme com o resultado daquele exame.

$\mathrm{O}$ incidente de revisão é regulado pela lei adjetiva aplicável à ação principal $^{16}$. Com efeito, o incidente carece de autonomia processual, consistindo em «qualquer questão que surge na pendência de uma causa, ligada aos termos que nela se discutem e que, por sua natureza, exige uma decisão especial.»17.

10 Cfr. Ac. do TR Porto de 9/12/2008, Proc. ${ }^{\circ} 0845614$ «A entidade responsável pela reparação do acidente de trabalho, cuja pensão foi oportunamente remida, não pode pedir a revisão da incapacidade, com fundamento na melhoria das lesões do sinistrado.»

11 Figura prevista no art. ${ }^{\circ} 857 .{ }^{\circ}$ do Cód. Civil: «Dá-se a novação objetiva quando o devedor contrai perante o credor uma nova obrigação em substituição da antiga.»

12 Cfr. Ac. TR Lisboa de 2/07/2003, Proc. ${ }^{\circ}$ 2095/2003-4.

13 Cfr. FIALHO, MANUELA BENTO, in Processo de acidentes de trabalho - os incidentes - ideias para debate, Prontuário de Direito do Trabalho, n. ${ }^{\circ} 69,2004$, p. 94.

14 Cfr. Ac. do TR Lisboa de 16/07/2009, 2528/09.7TTLSB.1.L1-4. «Requerido exame de revisão, se os peritos que integram a junta médica não atribuem uma incapacidade relativamente a uma data anterior à do exame, apenas estabelecendo o novo grau de IPP a partir da data do exame, a alteração do grau de incapacidade e, consequentemente, da pensão deve ser reportada à data do requerimento de revisão.»

15 Cfr. MENDES, MARLENE; ALMEIdA, SÉRgIO e BOTELHO, J0Ão, in Código de Processo do Trabalho Anotado, $1^{\text {a }}$ edição, Petrony, 2010. p. 212.

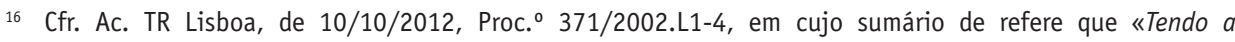
aç̧ão de acidente de trabalho sido instaurada em 23.10.2002 não é aplicável ao incidente de revisão da incapacidade nela deduzido em 14.10.2010 o regime processual decorrente do Decreto-Lei no 295/2009, de 13 de Outubro que entrou em vigor em 1 de Janeiro de 2010 mas o regime pré-vigente.»

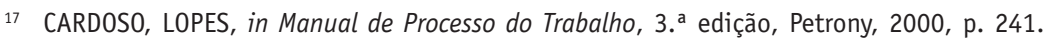


Quanto ao exame médico-legal de revisão da incapacidade, Teresa Magalhães, Isabel Antunes e Duarte Nuno Vieira ${ }^{18}$ salientam que «No capitulo do relatório pericial relativo à "Discussão" não é necessária a referência ao nexo de causalidade entre o traumatismo e o dano inicial, bastando referir se se verificou, ou não, alguma alteração relativamente ao quadro clínico anterior; ou seja, terá de se discutir o nexo de causalidade, sim, mas na perspectiva da imputabilidade do agravamento do quadro clínico anterior.»

Prevê-se também que o sinistrado curado sem incapacidade, faça uso desta faculdade, ainda que com as necessárias adaptações ${ }^{19}$, assunto ao qual adiante se voltará.

Adicionalmente, é regulada a possibilidade de a entidade responsável discutir a responsabilidade, total ou parcial, pelo agravamento ${ }^{20}$, caso em que, havendo necessidade de produção de outros tipos de prova que não a pericial, o processo segue os termos do processo comum.

Finalmente, em matéria de custas, aplica-se a este incidente o disposto no n. 4 do art. ${ }^{\circ}$ 7. $^{\circ}$ do Regulamento das Custas Processuais: a taxa de justiça devida é a prevista na Tabela II A - Outros incidentes ${ }^{21}$, cujo valor varia entre 0,5 e 5 UC's, devendo a parte efetuar a liquidação pelo valor mínimo e pagando o excedente, se o houver, a final, como emerge do n. ${ }^{\circ} 6$ do art. $^{\circ} 6^{\circ}$ do RCP.

18 In A avaliação do dano na pessoa no âmbito dos acidentes de trabalho e a nova Tabela Nacional de Incapacidades, Prontuário de Direito do Trabalho, n. ${ }^{0} 83,2009$, p. 161.

19 Desde logo, tem de ser tramitado em processo autónomo, pois não pode haver um incidente de um processo inexistente, cfr. Ac. da Relação de Coimbra de 7/09/2009, Proc. ${ }^{0}$ 602/04.6TTAVR.C1.

20 Diferente será se for rejeitada a responsabilidade pelo próprio acidente de trabalho, caso em que essa matéria tem de ser objeto de alegação e prova, cfr. Ac. do TR do Porto de 7/09/2009, Proc. ${ }^{\circ}$ 568/08.3TTVFR: «I- Nos termos do art. 145. ${ }^{\circ}, n .{ }^{\circ} 7$ do Código de Processo do Trabalho (CPT), o incidente de revisão pode ter lugar nos casos em que sendo responsável uma seguradora, o acidente não tenha sido participado ao tribunal em virtude do sinistrado ter sido considerado curado sem desvalorização. II- Não tendo havido participação do acidente por parte da seguradora, não foi deduzido processo por acidente de trabalho, pelo que não teve lugar qualquer diligência processual prévia, máxime, a tentativa de conciliação. III- Tendo a seguradora declarado, ao ser notificada para juntar aos autos a documentação do sinistrado, nos termos do art. ${ }^{\circ} 99 .{ }^{\circ}$, do CPT, que após averiguação realizada, o acidente não foi considerado da sua responsabilidade, impunha-se a realização de diligências com vista a se esclarecerem e apurarem os elementos necessários à fixação da pensão, sob pena de se coarctar àquela a possibilidade de se pronunciar sobre essa matéria e de exercer cabalmente o seu direito de defesa. IV- Só após a realização dessas diligências deveria ter sido decidido o incidente de revisão, mantendo, aumentando ou reduzindo a pensão - $\operatorname{art.}^{\circ} 145$, no 5 do CPT.»

21 Cfr. COSTA, SALVADOR DA, in Regulamento das Custas Processuais Anotado e Comentado, $4^{\mathrm{a}}$ edição, Almedina, 2012, p. 245 e seguintes. 


\section{b. A problemática do prazo para requerer a revisão}

Ainda na vigência da Lei 2127, foi suscitada a questão da inconformidade constitucional da norma que fixava o prazo de dez anos para requerer a revisão da incapacidade, invocando-se a violação dos princípios da igualdade $^{22}$ e da justa reparação dos acidentes de trabalho ${ }^{23}$.

Defendia-se que tal norma violava o princípio da igualdade por impedir a reparação da incapacidade decorrente de agravamento superveniente ocorrido para lá do prazo de dez anos, ao passo que a permitia ao trabalhador que pedisse revisão da incapacidade dentro desse prazo, bem como no caso de doença profissional ${ }^{24 / 25}$.

Existem numerosos acórdãos do Tribunal Constitucional a propósito desta temática, dos quais resulta o entendimento de que o facto de existir uma norma que estabelece um limite temporal - concretamente de 10 anos - para requerer a revisão da incapacidade, não viola a Constituição, pois não resulta desta, e especificamente do princípio da justa reparação dos acidentes de trabalho, que a lei ordinária deva consagrar uma possibilidade ilimitada de revisão da incapacidade.

Ademais, em algumas decisões, o TC considera que o prazo de 10 anos se mostra suficiente para assegurar aquele desiderato, pois o decurso de tal prazo sem alteração da incapacidade permite estabelecer uma presunção de consolidação e de estabilização das lesões ${ }^{26}$.

Só nos casos em que, durante os primeiros 10 anos, ocorreram revisões intercalares da incapacidade ${ }^{27}$ ou em que foi realizada uma cirurgia da qual acabou por resultar um agravamento da incapacidade ${ }^{28}$, elidindo, por consequência, a presunção de consolidação da situação clínica, é que o Tribunal Constitucional emitiu um juízo de inconstitucionalidade da norma, mas cujo alcance se limita à interpretação no sentido de considerar o prazo

22 Art. $^{\circ} 13^{\circ}$ da CRP: «Todos os cidadãos têm a mesma dignidade social e são iguais perante a lei.»

23 Alínea f) do n. ${ }^{\circ} 1$ do art. ${ }^{\circ} 59^{\circ}$ da CRP: «Todos os trabalhadores, sem distinção de idade, sexo, raça, cidadania, território de origem, religião, convicções políticas ou ideológicas, têm direito (...) a assistência e justa reparação, quando vítimas de acidente de trabalho ou de doença profissional.»

24 Neste sentido, CARVALHO, PAULO MORGADO DE, in Um olhar sobre o atual regime jurídico dos acidentes de trabalho: beneficios e desvantagens, Questões Laborais, Ano X, n. ${ }^{0} 21,2003$, p. 89.

25 A comparação com as doenças profissionais não se mostrava rigorosa, já que só as de caráter evolutivo beneficiavam - e bem - da inexistência de prazo de revisão.

26 É o caso do Ac. n. ${ }^{\circ}$ 155/2003, de 19/03, do Ac. n. ${ }^{\circ}$ 612/2008, de 10/12, do Ac. 411/2011, de 27/09, do Ac. $n .^{\circ} 219 / 2012$, de 26/04 e do Ac. n. ${ }^{0} 136 / 2014$, de 12/02.

27 Assim ocorreu no Ac. n. ${ }^{\circ}$ 147/2006, de 22/02 e no Ac. 59/2007, de 30/01.

28 Cfr. Ac. 161/2009, de 25/03. 
de 10 anos absolutamente preclusivo - portanto, sempre e em qualquer circunstância - do direito a pedir revisão.

Com o desaparecimento do prazo para pedir revisão da incapacidade operado pela Lei 98/2009, e apesar de a mesma estabelecer a sua aplicação apenas a acidentes ocorridos após a sua entrada em vigor, suscitou-se a questão da sua aplicação retroativa, permitindo a revisão da incapacidade sem dependência de prazo em processos emergentes de acidentes ocorridos antes de 1/01/2010.

O STJ pronunciou-se recentemente sobre a temática no Ac. de 22/05/201329 , Proc. $^{\circ}$ 201/1995.2.L1.S1, cujo sumário se reproduz: «I - $O$ princípio da igualdade, como parâmetro de apreciação da legitimidade constitucional do direito infraconstitucional, impõe que situações materialmente semelhantes sejam objecto de tratamento semelhante e que situações substancialmente diferentes tenham, por sua vez, tratamento diferenciado. II - À luz do regime jurídico previsto na Lei n. ${ }^{\circ}$ 2127, de 3 de Agosto de 1965, o sinistrado podia requerer a revisão da incapacidade no prazo de 10 anos contados da data da última fixação dessa incapacidade, que constitui, segundo a normalidade das coisas, um prazo suficientemente dilatado para permitir considerar como consolidada a situação clínica do sinistrado. III - A aplicação do novo regime da Lei n. ${ }^{\circ}$ 98/2009, de 4 de Setembro (que não prevê qualquer limitação temporal para requerer a revisão da incapacidade, e que só é aplicável aos acidentes ocorridos a partir de 1 de Janeiro de 2010) ao acidente dos autos - ocorrido no domínio de vigência da Lei n. ${ }^{\circ}$ 2127, de 3 de Agosto de 1965 - ofenderia, gravemente, a certeza e segurança do direito consolidado da seguradora, decorrente do artigo 2. ${ }^{\circ}$ da Constituição da República Portuguesa, sendo inaceitável que esta se veja confrontada com o ressurgimento desse direito, quando ele estava juridicamente extinto, à luz da lei que lhe é aplicável. IV - Assim, tratando-se dum acidente de trabalho sofrido na vigência da Lei n. ${ }^{\circ} 2127$, de 3 de Agosto de 1965, é de considerar extinto o direito do sinistrado a requerer exame de revisão da sua incapacidade quando tenham passado mais de dez anos desde a data da última fixação da incapacidade e o requerimento de realização desse exame de revisão.»

Estava em causa um acidente de trabalho regulado pela Lei 2127, tendo a sinistrada pedido revisão da incapacidade já na vigência da Lei 98/2009 e invocado o disposto no art. $^{\circ} 70 .^{\circ}$ desta lei, que regula o pedido

29 No mesmo sentido, o Ac. de 29/05/2013, Proc. ${ }^{\circ} 248-A / 1997 . C 1 . S 1$, não publicado, e o Ac. de 5/11/2013, Proc. ${ }^{\circ}$ 858/1997.2P1.S1. 
de revisão da incapacidade sem estabelecer qualquer prazo máximo para o efeito.

A defesa da aplicação do art. $.^{\circ} 70 .^{\circ}$ a acidentes regulados por leis anteriores $^{30}$ assenta em dois argumentos. Desde logo, na alegada violação do princípio da igualdade, uma vez que os sinistrados vítimas de acidentes de trabalho regulados pela atual LAT não têm prazo para requerer a revisão da incapacidade.

Parece-nos, salvo o devido respeito, que tal argumento prova demasiado, pois trata-se de uma consequência inevitável da alteração dos regimes legais e do necessário estabelecimento de fronteiras temporais entre a sua aplicação ${ }^{31}$. Mal seria se, sempre que uma lei vem introduzir um regime

30 Vd. o Ac. do TR Lisboa de 2/02/2011, Proc. ${ }^{0}$ 29/1990.1L1-4: «I. A Lei n. ${ }^{\circ 98 / 2009}$ de 4 de Setembro veio abolir qualquer limite temporal ao direito à revisão das prestações das vítimas de acidente de trabalho, o que a torna mais conforme com a norma do art. ${ }^{\circ} 59.0, n .{ }^{\circ} 1$ al. f) da Constituição que consagra o direito a uma justa reparação por parte das vítimas de acidente de trabalho ou doença profissional. II. Não é de manter uma interpretação restritiva da referida norma que impeça a reavaliação da incapacidade para as situações anteriores à data da entrada em vigor da Lei n. ${ }^{\circ}$ 98/2009.» e o Ac. do TR Lisboa de 8/02/2012, Proc. ${ }^{\circ}$ 231/1997.L1-4: «Não obstante 0 art. $187^{\circ}$ da L. 98/2009, de 4/9 determinar que a mesma apenas é aplicável aos acidentes ocorridos após a respectiva entrada em vigor, porque o desaparecimento, no art. ${ }^{\circ}$. $70^{\circ}$, do prazo preclusivo para requerer a revisão da incapacidade, como constava das leis de acidentes de trabalho anteriores, constitui verdadeiramente uma alteração do conteúdo da relação jurídica emergente de acidentes de trabalho, tem pertinência a aplicação dessa norma às situações jurídicas já constituídas à data da entrada em vigor da lei, em conformidade com o disposto na parte final do $n^{\circ} 2$ do art. ${ }^{\circ} 12^{\circ}$ do CC, o que é uma forma de assegurar o princípio constitucional da igualdade de tratamento.»

31 Vale a pena atentar no Ac. do TR Évora de 3/11/2009, Proc. ${ }^{0}$ 206/98.E1, com o sumário: «1. Enquanto prestação em dinheiro inserida no âmbito da reparação de um acidente de trabalho, o denominado 'subsídio para readaptação de habitação' foi introduzido no ordenamento jurídico português pela Lei $n^{\circ} 100 / 97$, de 13/9, sendo por isso apenas devido por acidentes ocorridos após 1/1/2000. 2. Na vigência da Lei $n^{\circ} 2127$, de 3/8/1965, e portanto relativamente a acidentes de trabalho anteriores àquela data, não era acolhida qualquer prestação semelhante, nem como reparação em espécie, nem como reparação em dinheiro.», pois, na sua fundamentação, contém este eloquente trecho, relativo à sucessão de leis no tempo: «Desta evolução legislativa resulta, a nosso ver de modo inequívoco, haver diferenças substanciais quanto ao âmbito daquele que é o direito à reparação devida em consequência de um acidente de trabalho, num e noutro dos regimes jurídicos em confronto (Lei $n^{\circ} 2127$, e Lei $n^{\circ}$ 100/97). Tendo este último diploma tido como reconhecido propósito alargar o âmbito da protecção conferida e sinistrados do trabalho e doentes profissionais, parece-nos de todo abusivo pretender-se que o novo subsídio para readaptação, introduzido pela lei como prestação em dinheiro para casos de incapacidade permanente absoluta, sendo limitado no seu montante, tinha afinal já pleno cabimento nas prestações em espécie que eram acolhidas pela Lei $n^{\circ} 2127$. É óbvio que o entendimento que perfilhamos pode acarretar diferenças de tratamento, segundo a data em que um ou outro acidente tenha ocorrido, podendo mesmo gerar casos de relativa injustiça material. Essa é, no entanto, consequência incontornável da existência duma sucessão de regimes legais, que tratam naturalmente de modo diverso, situações fácticas que são objectivamente semelhantes. É que se fosse para manter tudo na mesma, qualquer lei nova seria completamente inútil...» 
mais favorável, se brandisse o princípio da igualdade para defender a sua aplicação às situações reguladas pela lei anterior. ${ }^{32}$

Como sublinha o STJ, a aplicação retroativa da norma iria conflituar com o princípio da confiança, igualmente protegido na lei constitucional ${ }^{33}$. No caso concreto, essa aplicação retroativa teria, até, a perversidade de fazer renascer um direito que já se encontrava extinto na esfera jurídica da sinistrada ${ }^{34}$.

Também o Tribunal Constitucional tomou posição quanto à aplicação retroativa da abolição do prazo de revisão da incapacidade no Ac. n. ${ }^{\circ}$ $136 / 2014$, de 12/02, considerando que o princípio da igualdade não opera diacronicamente, pelo que não será aplicável ao fenómeno da sucessão de leis no tempo, o qual não afeta, só por si, aquele princípio e concluindo que «... a ponderação entre o princípio da igualdade e o princípio da segurança jurídica, em situação de confronto entre si resultante da alteração de regimes jurídicos, deve ser feita pelas normas instrumentais de conflitos, nomeadamente as normas transitórias. É neste âmbito que, visando precisamente garantir a segurança nas relações jurídicas entre sinistrado e entidade responsável pelo pagamento da pensão, a norma constante do artigo $187 .^{\circ}, n .^{\circ} 1 \mathrm{da} \mathrm{Lei}$ $n .^{\circ}$ 98/2009, veio estabelecer que o novo regime de revisão das pensões só vigora para os acidentes ocorridos após a publicação da lei que eliminou o limite de prazo para o efeito.»

Em segundo lugar, defende-se a aplicação do disposto no art. $^{\circ} 70 .^{\circ}$ a situações jurídicas constituídas antes da sua entrada em vigor, face ao

32 No Ac. do Plenário do Tribunal Constitucional n. ${ }^{\circ} 398 / 11$, de 22/09, considera-se, quanto a esta matéria, o seguinte: «apesar de uma alteração legislativa poder operar uma modificação do tratamento normativo em relação a uma mesma categoria de situações, implicando que realidades substancialmente iguais possam ter soluções diferentes, isso não significa que essa divergência seja incompatível com a Constituição, visto que ela é determinada, à partida, por razões de política legislativa que justificam a definição de um novo regime legal. Visando as alterações legislativas conferir um tratamento diferente a determinada matéria, a criação de situações de desigualdade, resultantes da aplicação do quadro legal revogado e do novo regime, é inerente à liberdade do legislador do Estado de Direito alterar as leis em vigor, no cumprimento do seu mandato democrático».

33 Art. ${ }^{\circ} 2^{\circ}$ da CRP «A República Portuguesa é um Estado de direito democrático, baseado na soberania popular, no pluralismo de expressão e organização política democráticas, no respeito e na garantia de efectivação dos direitos e liberdades fundamentais e na separação e interdependência de poderes, visando a realização da democracia económica, social e cultural e o aprofundamento da democracia participativa.»

34 Na sequência da publicação dos Ac. do TR Lisboa de 2/02/2011 e de 8/02/2012 acima citados, que defenderam essa aplicação retroativa, multiplicaram-se nos tribunais pedidos de revisão e quase outras tantas decisões a aceitá-los; assinala-se, em particular, um pedido de revisão num processo emergente de um acidente ocorrido em 1957 (regulado pois, pela Lei 1942, que previa um prazo de 5 anos para o efeito), vindo o sinistrado, já com 75 anos, pugnar pela atribuição de uma IPATH. 
disposto na parte final do n. ${ }^{\circ} 2$ do artigo $12 .^{\circ}$ do Código Civil ${ }^{35}$, norma que rege a aplicação das leis no tempo ${ }^{36}$.

Contudo, também este entendimento nos parece viciado na sua origem, pois a norma invocada aponta soluções que apenas são válidas para os casos em que haja dúvida quanto à lei a aplicar ${ }^{37}$. Ora, a Lei 98/2009 é muito clara, nos art. ${ }^{\text {os }} 187 .^{\circ}$ e $188 .^{\circ}$, ao revogar a lei anterior sem prejuízo da sua própria aplicação apenas aos acidentes ocorridos após a sua entrada em vigor, que o mesmo é dizer que a lei anterior é revogada, mas continua a produzir efeitos relativamente aos acidentes ocorridos até essa revogação. Assim, nenhuma dúvida se coloca.

O STJ foi, de resto, perentório no afastamento da aplicação do art. ${ }^{\circ} 12^{\circ}$ do Código Civil, por virtude de a Lei 98/2009 determinar expressamente que só se aplica aos acidentes ocorridos após a data da sua entrada em vigor, do que emerge que não se abstrai dos factos que estão na origem das situações que pretende regular ${ }^{38}$.

Analisando agora a solução da lei atual, mostra-se muito discutível a abolição do prazo de revisão da incapacidade, porquanto é praticamente

35 «1. A lei só dispõe para o futuro; ainda que, the seja atribuída eficácia retroactiva, presume-se que ficam ressalvados os efeitos já produzidos pelos factos que a lei se destina a regular. 2. Quando a lei dispõe sobre as condições de validade substancial ou formal de quaisquer factos ou sobre os seus efeitos, entende-se, em caso de dúvida, que só visa os factos novos; mas, quando dispuser directamente sobre o conteúdo de certas relações jurídicas, abstraindo dos factos que thes deram origem, entender-se-á que a lei abrange as próprias relações já constituídas, que subsistam à data da sua entrada em vigor.» (destaques nossos).

36 No mesmo sentido, NETO, ABÍLIO, in Acidentes de Trabalho e Doenças Profissionais - Anotado, $1^{\text {a }}$ edição, 2011, p. 200: «Esta norma [art. ${ }^{\circ} 70^{\circ}$ da LAT], atento o disposto na 2. ${ }^{a}$ parte do $n .{ }^{\circ} 2$ do art. ${ }^{\circ} 12 .{ }^{\circ}$ do Código Civil, abrange as próprias relações já constituídas, que subsistam à data da entrada em vigor da Lei n. ${ }^{\circ}$ 98/2009, de 4-9.»

37 ASCENSÃO, JOSÉ DE OLIVEIRA, in 0 Direito - Introdução e teoria geral, $2^{a}$ edição, Fundação Calouste Gulbenkian, 1980, p. 434 refere, quanto ao disposto no $\mathrm{n} .{ }^{\circ} 2$ do art. ${ }^{\circ} 12^{\circ}$ do CC, que «Perante este critério, devemos observar desde logo que na primeira parte se estabelece que a regra se aplica em caso de dúvida, enquanto que na segunda parte não se encontra restrição semelhante. Mas supomos que a disposição é genérica. A assimetria é devida apenas a questão de redaç̧ão, e o entender-se-á da segunda parte tem a função de exprimir por outras palavras o "entende-se em caso de dúvida" da primeira.» Depois, quanto ao alcance da restrição "em caso de dúvida", expende que "Isto significa que, se a situação tiver uma solução categórica se aplica tal solução; se a não tiver, se a ambiguidade se mantiver, aplica-se a regra subsidiária legal. Mas quando se pode dizer que a situação tem uma solução categórica? (...) Supomos que só não há dúvida quando os dados normativos impuserem certa solução. Se não houver nenhum preceito específico ou se os preceitos existentes não bastarem para afastar a ambiguidade, aplicam-se então as regras do art. ${ }^{\circ}$ 12, com a mesma imperatividade de qualquer outra regra jurídica.»

38 Neste sentido, vide JOÃO DIOGO DUARTE, in Apontamentos sobre o regime vigente de reparação de danos resultantes de acidentes de trabalho, Revista Semestral do Instituto de Seguros de Portugal, Ano XVIII, n. ${ }^{\circ}$ 34, Abril de 2014, p. 96/97, disponivel em http://www.isp.pt/NR/rdonlyres/19FB9562-CCE4-4859A80B-5338C071D42F/0/F\%C3\%B3rum34.pdf 
impossível, vinte, trinta ou mais anos depois de um acidente, verificar se a situação clínica que o sinistrado apresenta provém desse acidente ou de qualquer outra causa, nomeadamente de outros acidentes, do normal desgaste do organismo ${ }^{39}$ ou de desgastes físicos específicos, causados por fatores atinentes ao tipo de vida e atividade do mesmo, que só ele conhece e que, naturalmente, pedindo a revisão, é do seu interesse omitir.

Adicionalmente, constata-se que apenas numa ínfima parte, porventura inferior a 5\% dos pedidos de revisão, o sinistrado refere que precisa de assistência clínica. Da alegação de que está pior, emerge somente o pedido de aumento da percentagem da incapacidade, a demonstrar que a grande maioria dos pedidos de revisão têm um cariz eminentemente financeiro, o que deveria determinar maior rigor na definição dos requisitos deste instituto $^{40}$. Aliás, pensamos que a crise económica constitui o principal motivo do aumento massivo dos pedidos de revisão da incapacidade registado nos últimos anos, à semelhança, aliás, dos pedidos de remição parcial.

Compreende-se e aceita-se a preocupação do legislador em não afastar a reparação quando existe um efetivo agravamento clínico resultante do acidente de trabalho, mas, como vem sendo frequente no âmbito dos acidentes de trabalho, os objetivos são transformados ipsis verbis em letra de lei, sem ponderar devidamente as soluções em todas as suas implicações e criando fontes de iniquidade e de injustiça.

O desiderato pretendido poderia ser alcançado através de uma solução mais equilibrada, designadamente, alargando o prazo para quinze, ou mesmo vinte anos ou prevendo prazos específicos, ou a ausência de prazo, para cada tipo de lesão, de acordo, respetivamente, com o seu caráter evolutivo ou com a falta dele.

Por outro lado, deveria ser estabelecido um limite de idade para pedir a revisão. Tal limite deve coincidir com a idade da reforma, pois não se mostram admissíveis situações como temos visto, de sinistrados que, encontrando-se já reformados, vão ao tribunal do trabalho invocar que a sua incapacidade para o trabalho agravou, para que lhes seja aumentado o respetivo grau e,

39 Desgaste que o legislador tão claramente afasta do âmbito de proteção das doenças profissionais, no n. ${ }^{\circ} 2$ do art. ${ }^{\circ} 94$ da Lei 98/2009: «A lesão corporal, a perturbação funcional ou a doença não incluídas na lista a que se refere o número anterior são indemnizáveis desde que se prove serem consequência necessária e directa da actividade exercida e não representem normal desgaste do organismo.»

40 Mesmo em matéria de custas, a responsabilidade pelo pagamento dos exames de revisão é sempre da seguradora, ainda que 0 incidente venha a improceder, cfr. $n .{ }^{\circ} 8$ do art. ${ }^{0} 17^{\circ}$ do RCP: «Nas acções emergentes de acidente de trabalho ou de doença profissional incumbe à pessoa legalmente responsável pelo acidente ou pela doença, ainda que isenta de custas, o pagamento da remuneração aos peritos e da despesa realizada com autópsias ou outras diligências necessárias ao diagnóstico clínico do efeito do sinistro ou da doença.». 
inclusivamente, pugnar pela atribuição de uma incapacidade permanente absoluta para o trabalho habitual.

Em Espanha ${ }^{41}$, a Ley General de la Seguridad Social permite a revisão da incapacidade até que o sinistrado complete a idade da reforma. Idêntica solução vigora na Suíça.

Na Áustria, ao sinistrado que não atingiu 50 anos em 1/01/2014, é assegurada uma pensão de invalidez no caso de incapacidade permanente para o trabalho habitual. Se o sinistrado já atingiu a idade de 50 anos naquela data, a pensão de invalidez é atribuída por um período máximo de 24 meses, após o que é submetido a um exame médico, podendo a pensão ser renovada por outros 24 meses. Só é atribuída uma pensão sem prazo limite, se a incapacidade puder ser assumida como permanente, devido à situação física ou mental da pessoa.

Na Bélgica, o art. ${ }^{\circ} 72 .^{\circ}$, da Loi sur les accidents du travail, de 10 de Abril de 1971, prevê a possibilidade de revisão da incapacidade resultante de acidente de trabalho no prazo de 3 anos $^{42}$.

Na Dinamarca e na Finlândia, prevê-se a revisão da pensão caso o pensionista regresse ao trabalho.

Em França e na Alemanha, é revista a pensão se ocorrer uma alteração na incapacidade, sem dependência de prazo.

Em Itália, a pensão pode ser revista a cada três anos, num máximo de três revisões, após o que se torna inalterável.

Na Noruega a pensão pode ser revista a qualquer momento e no Reino Unido o único requisito é a ocorrência de uma alteração da situação clínica ${ }^{43}$.

41 «La revisión de las situaciones de incapacidad puede producirse en cualquier momento siempre que el trabajador incapacitado no haya cumplido la edad mínima de jubilación - 65 años- y procede por las siguientes causas: agravación, mejoría o por error en el diagnóstico. En todas las resoluciones del INSS, iniciales o de revisión, que reconozcan el derecho a prestaciones de incapacidad permanente, en cualquiera de sus grados, o confirmen el grado reconocido previamente, ha de constar necesariamente el plazo a partir del cual se puede instar revisión por agravación o mejoría. No obstante, si los pensionistas de incapacidad están trabajando, por cuenta ajena o propia, el INSS puede, de oficio o a instancia del interesado, promover la revisión con independencia de que haya o no transcurrido el plazo señalado en la resolución. Si la revisión está fundada en error de diagnóstico, puede llevarse a cabo, siempre con el límite de edad indicado, en cualquier momento.» informação disponível em http://www.mutualia.es/es/accidente-de-trabajo-y-enfermedad-profesional/93-revision-de-las-incapacidades

42 «La demande en révision des indemnités, fondée sur une modification de la perte de capacité de travail de la victime ou (de la nécessité de l'aide régulière d'une autre personne ou sur le décès de la victime) dû aux conséquences de l'accident, peut être introduit dans les trois ans qui suivent la date de l'homologation (ou de l'entérinement) de l'accord entre les parties ou de la décision ou de la notification visée à l'article 24 (ou de la date de l'accident si l'incapacité temporaire de travail ne dépasse pas sept jours et si l'entreprise d'assurances déclare la victime guérie sans incapacité permanente de travail).»

43 Elementos de direito comparado disponíveis e consultáveis no sítio da internet http://www.missoc.org/ MISSOC/INFORMATIONBASE/COMPARATIVETABLES/MISSOCDATABASE/comparativeTablesSearch.jsp 


\section{c. As situações de cura sem incapacidade}

O instituto da revisão da incapacidade, denominado nas sucessivas legislações como revisão da pensão e, mais recentemente, revisão das prestações, inculca a ideia de ter sido concebido e, por conseguinte, estar vocacionado, apenas para as situações em que do acidente de trabalho resultou uma incapacidade, a qual foi depois avaliada e fixada judicialmente, através do processo próprio. Ademais, a própria epígrafe da norma adjetiva - revisão da incapacidade em juízo - parece apontar nesse sentido.

Contudo, o atual Código de Processo do Trabalho, aprovado pelo D.L. n. ${ }^{\circ}$ 480/99, de 9/11, cuja entrada em vigor teve lugar em 1/01/2000, introduziu uma nova disposição no artigo $145 .^{\circ}$, concretamente o n. ${ }^{\circ} 7^{44}$, com a seguinte redação: «O disposto nos números anteriores é aplicável, com as necessárias adaptações, aos casos em que, sendo responsável uma seguradora, o acidente não tenha sido participado ao tribunal por o sinistrado ter sido considerado curado sem incapacidade.»

É, assim, inquestionável a possibilidade de um sinistrado, que ficou curado sem incapacidade, portanto, sem sequelas valorizáveis, requerer a revisão da sua "incapacidade", entendendo-se esta, forçosamente, em termos amplos, como situação clínica.

De resto, mesmo em relação a acidentes anteriores à entrada em vigor da mencionada norma, a jurisprudência é favorável à revisão da incapacidade dos sinistrados sem sequelas incapacitantes. É o que emerge do Ac. do TR de Coimbra de 7/09/2009, Proc. ${ }^{\circ}$ 602/04.6TTAVR.C1, em cujo sumário se pode ler «I - Nos termos da Base XXII, $n^{\circ} 1$, da Lei $n^{\circ} 2127$, de 3/08/1965, "quando se verifique a modificação da capacidade de ganho da vítima proveniente de agravamento, recidiva, recaída ou melhoria da lesão ou doença que deu lugar à reparação... as prestações poderão ser revistas e aumentadas, reduzidas ou extintas, de harmonia com a alteração verificada". II - O que importa, para o efeito, é que tenha havido um acidente de trabalho e que este tenha dado origem a incapacidades mesmo que temporárias, com o recebimento das correspectivas indemnizações, para além do nexo causal entre o sinistro e as actuais lesões. III - Logo, é sempre possível a revisão da incapacidade, mesmo que não resulte do acidente nenhuma IP (portanto, mesmo em situação de cura sem incapacidade).»

Neste aresto, é apresentado um argumento que nos parece sólido, na defesa da possibilidade de revisão da incapacidade nestas situações, que é o

44 Atualmente, corresponde ao n. ${ }^{\circ} 8$, com a introdução de mais um número no art. ${ }^{\circ} 145^{\circ}$, efetuada pelo D.L. n. ${ }^{\circ}$ 295/2009, de 13 de Outubro. 
de a lei prever como fundamento de revisão, não apenas o agravamento e a recaída, mas também a recidiva, sendo que esta consiste no «reaparecimento da enfermidade, mais ou menos tempo depois de decorrido um período de saúde completa, após ter sido debelada uma primeira vez $z^{45}$ ».

Por outro lado, sendo o escopo do instituto em causa assegurar que a reparação corresponda ao efetivo grau de incapacidade, a sua extensão aos sinistrados curados sem incapacidade é, sem dúvida, pertinente.

Contudo, não nos termos em que se encontra plasmada na lei.

Desde logo, esta matéria não deveria estar regulada em norma adjetiva; a sua sede natural é o art. ${ }^{\circ} 70 .^{\circ}$ da LAT, onde se regula o direito a pedir revisão da incapacidade. Com efeito, uma norma substantiva consagra o direito, cabendo somente à norma adjetiva a previsão do modo de o efetivar.

Depois, é importante fazer o cotejo desta norma com o prazo de caducidade do direito de ação previsto no n. ${ }^{\circ} 1$ do art. ${ }^{\circ} 179 .^{\circ}$ da $\mathrm{LAT}^{46}$, pois, dispondo o sinistrado curado sem incapacidade de um ano para participar o acidente ao tribunal, o seu direito de ação caduca decorrido esse prazo ${ }^{47}$. Todavia, não raro, assiste-se à utilização do incidente de revisão da incapacidade quando o prazo de um ano já decorreu. É um expediente muito em voga nos tribunais do trabalho: o sinistrado apresenta uma participação claramente caducada e a mesma é, pura e simplesmente, convertida em pedido de revisão, o que permite contornar a caducidade, esvaziando de conteúdo a norma que a prevê, mais a mais, com apoio numa norma adjetiva, que assim retira aplicação prática a uma norma de caráter substantivo ${ }^{48}$.

$\mathrm{O}$ assunto torna-se acrescidamente problemático atento o facto de a nova LAT já não prever qualquer limite temporal para a apresentação do pedido de revisão.

Atento o exposto, no âmbito de acidentes regulados pela Lei 98/2009, poderão surgir pedidos de revisão por parte de sinistrados curados sem sequelas enquanto os mesmos viverem. E se isso já é muito questionável relativamente aos sinistrados com sequelas, pois deveria ser previsto um prazo máximo para o efeito, nas situações de ausência de sequelas, por maioria de razão, mais sentido faria a fixação de um prazo.

45 ALEGRE, CARLOS, ob. cit., p. 127.

46 «0 direito de acção respeitante às prestações fixadas na presente lei caduca no prazo de um ano a contar da data da alta clínica formalmente comunicada ao sinistrado ou, se do evento resultar a morte, a contar desta.»

47 Alguma da nossa jurisprudência resolve esta questão de uma forma que temos por demasiado superficial, pois considera que o prazo de caducidade não é aplicável aos sinistrados curados sem incapacidade que peçam revisão: vide Ac. do TR de Coimbra de 12/02/2009, Proc. ${ }^{0}$ 602/04.6TTAVR.C1.

48 As normas adjetivas ou processuais têm caráter instrumental relativamente ao direito substantivo, cfr. ASCENSÃO, JOSÉ DE OLIVEIRA, ob. cit., p. 306. 
Discordamos do Ac. do TR de Coimbra de 12/02/2009, que refere: «E como nos parece óbvio, um caso de cura sem incapacidade é tão susceptível de se modificar como uma qualquer incapacidade.» Efetivamente, isso não se mostra óbvio, afigurando-se, ao invés, que uma lesão que curou totalmente apresenta maior probabilidade de consolidação do que uma outra que deixou sequelas.

Deveria, pois, ser estabelecido um prazo máximo (vg. de cinco anos), volvidos os quais, não havendo agravamento, se teria a situação clínica por consolidada.

Contudo, a nossa maior discordância da norma contida no n..$^{\circ} 8$ do art. $^{\circ}$ $145^{\circ}$ do CPT radica na restrição que a mesma faz ao direito do sinistrado curado sem incapacidade: só se a entidade responsável for uma seguradora é que o sinistrado, afinal, tem direito a que a sua incapacidade seja revista.

Não parece aceitável que o legislador use de diferentes critérios em relação a matérias iguais, dependendo de quem seja o responsável. Existem várias aflorações desse modo sui generis de legislar quando está em causa a responsabilidade de uma seguradora ou a responsabilidade do próprio Estado $^{49}$. Esta norma revela que o empregador também é beneficiário dessa discriminação legislativa.

Se esta norma já se apresenta muito discutível, por permitir fazer letra morta do prazo de caducidade e por não apresentar qualquer limitação temporal, fica definitivamente em causa com esta inexplicável salvaguarda do empregador, ou, note-se, do Fundo de Acidentes de Trabalho (FAT), em caso de insuficiência económica daquele.

Não há qualquer limitação do género quando a entidade responsável é o empregador ou o FAT e se está perante um sinistrado com incapacidade, pelo que parece, bem vistas as coisas, que as duas situações não são tão equiparáveis, ao ponto de o legislador não ter pejo de afastar o direito do sinistrado sem sequelas, por muito que a sua situação clínica possa ter-se agravado, se o responsável não for uma seguradora.

49 Basta comparar os regimes da reparação das doenças profissionais e da reparação dos acidentes de trabalho ao serviço de entidades empregadoras públicas com o regime da reparação dos acidentes de trabalho. A título de exemplo: em vão se procura no segundo uma norma equivalente à do art. ${ }^{\circ} 136^{\circ}$ da LAT (acumulação das prestações por doença profissional com rendimentos do trabalho), ou à do art. ${ }^{\circ} 41^{\circ}$ (acumulação de prestações) do DL 503/99, de 20/11, sendo que faria idêntico sentido. 0 mesmo se diga do n. ${ }^{\circ} 2$ do art. $^{\circ}$ $153^{\circ}$ da LAT (dever de o beneficiário de pensão por morte resultante de doença profissional comunicar casamento ou união de facto): 0 art. ${ }^{\circ} 59^{\circ}$ da LAT nada prevê de semelhante. A salvaguarda contida no n. ${ }^{\circ} 5$ do art. $^{\circ} 46^{\circ}$ do DL 503/99, relativa a situações em que 0 acidente resulta de responsabilidade de terceiros, também não encontra qualquer paralelo no art. $^{0} 17^{\circ}$ da LAT, sem que se perceba porque assim não ocorre. E nestas situações, de nada adianta invocar em tribunal a aplicação analógica, pois a mesma é rejeitada. 
Ora, se o responsável não é uma seguradora, tal significa que o empregador não tinha a responsabilidade validamente transferida, caso em que é obrigado a prestar caução, nos termos previstos no n. ${ }^{\circ} 1$ do art. $^{\circ} 84 .^{\circ}$ da LAT, a menos que celebre um contrato de seguro de pensões, como dispõe a parte final da mesma norma.

Se o empregador não caucionar a sua responsabilidade, nem celebrar tal seguro, designadamente por incapacidade económica, os encargos pela reparação do acidente são assumidos pelo FAT, nos termos do n. ${ }^{\circ} 1$ do art. $^{\circ}$ $82 .{ }^{050}$ da LAT e da al. a) do n. ${ }^{\circ} 1$ do art. $^{\circ} 1$. $^{\circ}$ do DL $142 / 99$, de 30/0451.

O FAT, por seu turno, é financiado através de receitas várias, designadamente provindas de contribuições dos tomadores de seguros (integradas no valor do prémio do contrato de seguro de acidentes de trabalho), das empresas de seguros, de aplicações financeiras, do produto das coimas, etc.

Não se vislumbra, portanto, um fundamento válido, quer de um ponto de vista jurídico, quer de um ponto de vista ético, para criar uma distinção de regime desta índole, a qual se afigura, de resto, enfermar de inconstitucionalidade, atento o princípio da igualdade.

\section{0 factor de bonificação}

\section{a. Âmbito de aplicação}

A avaliação e graduação da incapacidade resultante de acidente de trabalho encontram-se reguladas no art. $^{\circ} 21 .^{\circ}$ da LAT: «1 - O grau de incapacidade resultante do acidente define-se, em todos os casos, por coeficientes expressos em percentagens e determinados em função da natureza e da gravidade da lesão, do estado geral do sinistrado, da sua idade e profissão, bem como da maior ou menor capacidade funcional residual para o exercício de outra profissão compatível e das demais circunstâncias que possam influir na sua capacidade de trabalho ou de ganho. (sublinhado nosso). 2 - O grau de incapacidade é expresso pela unidade quando se verifique disfunção total com incapacidade permanente absoluta para todo e qualquer trabalho. 3 - O

${ }^{50}$ «A garantia do pagamento das pensões estabelecidas na presente lei que não possam ser pagas pela entidade responsável, nomeadamente por motivo de incapacidade económica, é assumida e suportada pelo Fundo de Acidentes de Trabalho, nos termos regulamentados em legislação especial.»

51 Na qual se prevê que incumbe ao FAT «Garantir o pagamento das prestações que forem devidas por acidentes de trabalho sempre que, por motivo de incapacidade económica objectivamente caracterizada em processo judicial de falência ou processo equivalente, ou processo de recuperação de empresa, ou por motivo de ausência, desaparecimento ou impossibilidade de identificação, não possam ser pagas pela entidade responsável;» 
coeficiente de incapacidade é fixado por aplicação das regras definidas na Tabela Nacional de Incapacidades por Acidentes de Trabalho e Doenças Profissionais, em vigor à data do acidente.»

Por sua vez, a Tabela Nacional de Incapacidades em vigor, aprovada pelo Decreto-Lei 352/2007, de 23/10, dispõe, na al. a) do n. ${ }^{\circ}$ das respetivas Instruções Gerais, que: "Os coeficientes de incapacidade previstos são bonificados, até ao limite da unidade, com uma multiplicação pelo factor 1.5, segundo a fórmula: IG + (IG $\times 0.5)$, se a vítima não for reconvertível em relação ao posto de trabalho ou tiver 50 anos ou mais quando não tiver beneficiado da aplicação desse factor.»

Como resulta da análise do art. $^{\circ} 21 .^{\circ}$ acima transcrito, a idade deve ser considerada aquando da avaliação do grau de incapacidade. E cremos que bem, pois a mesma lesão pode ter um impacto diferente, ser mais ou menos incapacitante, consoante as caraterísticas da pessoa do sinistrado, designadamente, a sua capacidade física e psíquica de superação e de recuperação $0^{52}$, nas quais a idade pode influir decisivamente, sendo um fator relevante a considerar na avaliação sequelar ${ }^{53}$.

Por outro lado, justamente por virtude de as lesões não terem o mesmo impacto em todas as pessoas, encontra-se prevista para cada lesão uma determinada amplitude de avaliação ${ }^{54}$, ao que acresce a possibilidade, conferida pelo n. 7 das Instruções Gerais ${ }^{55}$, de o perito se afastar dos coeficientes previstos na Tabela ${ }^{56}$.

52 Daí que, no meio clínico, se ouça com frequência o aforismo "não há doenças; há doentes".

53 MAGALHÃES, TERESA; ANTUNES, ISABEL e VIEIRA, DUARTE NUNO, ob. cit. p. 168, defendem, a este propósito: «(...) apesar de todas as possiveis metodologias, cada caso é único e o que é adequado a uma vítima não é necessariamente indicado para outra, ainda que com sequelas lesionais e funcionais comparáveis. $A$ função do perito é avaliar um dano de forma personalizada e traduzir a sua complexidade por palavras simples, para que todos os intervenientes no processo o possam apreciar sobres bases concretas e proporcionar uma reparação adequada, assim se cumprindo o motivo último da intervenção pericial médico-legal: o indivíduo e a realização da Justiça do caso concreto.»

54 CORTE-REAL, FRANCISCO; TAVARES, S.; CORDEIRO, C. et al., in A Tabela Nacional de Incapacidades e o factor 1,5, Revista Portuguesa do Dano Corporal, 2004, n. ${ }^{\circ}$ 14, p 92, referem de forma lapidar: «Salienta-se (...) que não concordamos com a existência de um factor de bonificação previsto para aumentar coeficientes de incapacidade quando a TNI contempla múltiplos intervalos valorativos, admitindo mesmo a possibilidade de que o perito possa propor a fixação de valores superiores dos consignados na tabela desde que fundamentadamente justificados.»

55 «Sempre que circunstâncias excepcionais o justifiquem, pode ainda o perito afastar-se dos valores dos coeficientes previstos, inclusive nos valores iguais a 0.00 expondo claramente e fundamentando as razões que a tal o conduzem e indicando o sentido e a medida do desvio em relação ao coeficiente em princípio aplicável à situação concreta em avaliação.»

56 MAGALHÃES, TERESA; ANTUNES, ISABEL e VIEIRA, DUARTE NUNO, in ob. cit., p. 164, afirmam que « (...) as tabelas não são um mal em si mesmo, mas já o será o facto de algumas delas serem vinculativas ou o 
Face ao exposto, não se mostra curial a consideração automática da idade imposta pela TNI sempre que o sinistrado tenha 50 ou mais anos de idade, atribuindo-lhe mais $50 \%$ da incapacidade que resulta da avaliação propriamente dita e na qual, como vimos, já é considerada a idade.

Esta bonificação, figura que julgamos ímpar no cotejo com outros ordenamentos jurídicos, assenta numa mera ficção e abstração, em claro prejuízo da avaliação do impacto concreto e efetivo das sequelas na capacidade de trabalho. A este propósito, é de salientar a perplexidade manifestada por Teresa Magalhães, Isabel Antunes e Duarte Nuno Vieira ${ }^{57}$ : «E quais os fundamentos científicos para a atribuição deste coeficiente que não é mais que uma abstracção aritmética que presume fazer uma avaliação rigorosa quando a torna ainda mais abstracta, confusa e alheada da realidade de cada caso concreto?»

Já Albertina Aveiro Pereira tem uma visão diversa, muito favorável à figura do factor de bonificação ${ }^{58}$. Embora concordemos com o entendimento na sua essência, pois a idade deve ser um dos aspetos a considerar numa avaliação que se quer justa e adequada, não subscrevemos a bonificação indiscriminada e automática, pois ela constitui a antítese daquele objetivo.

Trata-se de uma disposição não assente em qualquer racional médico ${ }^{59}$, à semelhança de outras igualmente presentes nas Instruções Gerais da TNI, como é o caso da prevista no n. ${ }^{0} 9^{60}$; consagram regras que têm menos a ver com a estrita avaliação do dano corporal, e mais com opções políticas quanto

serem assumidas como tal por alguns "peritos". Com efeito, elas não podem ser mais do que um simples instrumento pericial auxiliar do perito, apenas podendo ter um caráter meramente indicativo. Devemos também ter presente que nenhuma tabela pode contemplar as especificidades de cada caso, competindo ao perito colher as indicações da tabela, inserindo nas suas linhas de orientação as especificidades do caso que foi chamado a apreciar. 0 perito serve-se da tabela, não serve a tabela.»

57 Ob. cit. p. 158.

58 «A bonificação traduz-se, assim, num factor de correç̧ão, atendendo a casos particularmente gravosos ou injustos para o sinistrado, que não seriam devidamente tutelados com a "pura e simples" atribuição dos coeficientes previstos na TNI. Essas situações prendem-se com a idade do sinistrado (50 anos ou mais) e com a sua reconvertibilidade no posto de trabalho, factores que não resultando da aplicação dos coeficientes em si, a lei não quis deixar de tomar em consideração, face à situação mais penosa desses sinistrados, inserindo, assim, o dito factor de ajustamento ou correcção. Aliás, a consagração desse factor, encontra-se em perfeita harmonia com o proclamado no preâmbulo do próprio diploma legal que aprovou a TNI, onde o legislador fazendo apelo a uma visão humanista e integral do (homem) sinistrado diz, expressamente, que a tabela aprovada deve contribuir para a "humanização da avaliação da incapacidade, numa visão não exclusiva do segmento atingido, mas do indivíduo como um todo físico e psíquico, em que seja considerada não só a função mas também a capacidade de trabalho disponível"», in Acidentes de trabalho (os exames médicos e a Tabela Nacional de Incapacidades), Prontuário de Direito do Trabalho n. ${ }^{\circ} 70,2005$, p. 223 e segts.

59 Sendo, de resto, frequentemente aplicada pelo tribunal sem que os médicos se tenham pronunciado acerca da sua aplicação.

60 «As incapacidades temporárias parciais correspondentes ao primeiro exame médico são fixadas pelo menos no dobro do coeficiente previsível numa futura situação de incapacidade permanente.» 
ao modo de indemnizar esse dano. São comandos que transcendem qualquer lógica médico-pericial, tendo apenas impacto no quantum da indemnização.

Desde logo, estas matérias, sem prejuízo de carecerem de revisão e de atualização ${ }^{61}$, deveriam figurar na LAT, na seção que constitui a sua sede própria, intitulada "Natureza, determinação e graduação da incapacidade" (artigos $19 .^{\circ}$ a $22 .^{\circ}$ ).

A TNI deveria ser uma tabela estritamente médica; o facto de ter um conteúdo político aumenta a resistência à sua atualização, mostrando-se pertinente a depuração desse conteúdo não estritamente clínico, que impede a sua tão necessária modernização e a torna refém de soluções de discutível bondade e justiça, porque assentes em ficções e presunções, em vez de critérios puramente médicos.

O escopo exclusivo da tabela deve ser a avaliação do dano, deixando as regras indemnizatórias para o regime legal dos acidentes de trabalho; só assim poderá evoluir-se no sentido da avaliação real do impacto das sequelas na capacidade de ganho e no rendimento do sinistrado, pois a reparação dos acidentes de trabalho, para ser justa, deve indemnizar os prejuízos efetivos ${ }^{62}$.

Por ora, esta TNI queda-se anquilosada pelo seu conteúdo político, já que a abertura da discussão em seu torno é condicionada pelo facto de qualquer alteração da mesma ter um impacto direto nos valores a indemnizar. A dificuldade de um consenso constituirá, por certo, a razão que explica a ausência de revisões e atualizações da mesma.

Entretanto, a figura do fator 1,5, para lá de estar mal concebida, vai sendo objeto de critérios de aplicação muito discutíveis, com interpretações desajustadas, que em nada honram o princípio da justa reparação, e transformam o regime dos acidentes de trabalho numa fonte de benefícios injustificados.

A atribuição do fator de bonificação pressupõe a verificação de um dos três seguintes fundamentos:

610 DL 352/2007 que aprovou a atual TNI, previu a criação de uma comissão permanente "visando um constante acompanhamento da sua correcta interpretação e aplicação e também a sua periódica revisão e atualização»; contudo, volvidos sete anos de vigência, a mesma mantém a versão original. Por outro lado, a sua interpretação e aplicação têm vindo a conhecer alguns atropelos, designadamente no âmbito do factor de bonificação, como infra se procurará demonstrar.

62 MAGALHÃES, TERESA; ANTUNES, ISABEL e VIEIRA, DUARTE NUN0, ob. cit, p. 166, defendem uma harmonização da avaliação e reparação do dano na pessoa, com independência do ramo do Direito em que a mesma decorra, e com referência a um procedimento comum europeu, no que se refere a conceitos e metodologias aplicáveis: «0 que poderá distinguir estas perícias (Direito Civil, Penal ou do Trabalho) são os tipos de parâmetros de dano considerados em cada caso; apesar disso, e no que se refere à "Incapacidade Permanente", avaliada através de tabelas médicas, não faz sentido, em termos técnico-científicos, que estas tabelas sejam diferentes conforme o contexto legal do caso.» 
- o sinistrado não é reconvertível em relação ao posto de trabalho,

- o sinistrado tem 50 ou mais anos de idade ou

- a lesão implica alteração visível do aspeto físico, afetando de forma relevante o desempenho do posto de trabalho.

Desde logo, tem-se assistido à atribuição do factor 1,5, sem que se verifique qualquer dos três requisitos que a TNI prevê para o efeito, em nome de uma alegada liberdade conferida pelo n. ${ }^{\circ} 7$ das Instruções Gerais da TNI. A bonificação tem sido atribuída a sinistrados: 1) reconvertidos no seu posto de trabalho, 2) com idade inferior a 50 anos e 3) sem alteração visível do aspeto físico, que afete de forma relevante o desempenho do posto de trabalho, com base num quarto fundamento, que é o facto de o sinistrado ter de desenvolver esforços acrescidos para continuar a desempenhar a sua função. Como se a atribuição da incapacidade parcial permanente não refletisse já o impato da sequela no exercício da atividade, impacto esse que se traduz, justamente, em tornar mais penoso tal exercício.

Foi pela via dos esforços acrescidos que a bonificação foi introduzida nos processos de acidente de trabalho dos praticantes desportivos profissionais, âmbito onde ainda se torna mais gritante a injustiça, porquanto os mesmos já beneficiam de uma majoração da incapacidade com base na idade, por via da tabela de comutação específica prevista no diploma legal que rege tais acidentes ${ }^{63}$.

O Supremo Tribunal de Justiça pôs recentemente cobro a este desvio interpretativo, através do Ac. de 28/05/2014, publicado no DR, 1. ${ }^{a}$ Série, de 30/06/2014, uniformizador de jurisprudência, com o seguinte sumário: «1 - $A$ expressão "se a vítima não for reconvertível em relação ao posto de trabalho" contida na alinea a) do n. 5 das Instruções Gerais da Tabela Nacional de Incapacidades por Acidente de Trabalho ou Doenças Profissionais, aprovada pelo Decreto-Lei n. 352/2007, de 23 de Outubro, refere-se às situações em que o sinistrado, por virtude das lesões sofridas, não pode retomar o exercício das funções correspondentes ao concreto posto de trabalho que ocupava antes do acidente; 2 - Não é possível bonificar, nos termos da alínea a) do n. ${ }^{\circ} 5$ daquelas Instruções Gerais, o coeficiente de incapacidade geral de um profissional de futebol decorrente de acidente de trabalho, de 22 anos à data do acidente, e que retomou, logo após a alta, as tarefas correspondentes ao posto profissional que ocupava antes do acidente.».

Posteriormente, o Ac. do Supremo de 17-09-2014, tirado no Proc. ${ }^{\circ}$ 2426/10.2TTLSB.L1.S1, veio tornar claro que o entendimento expresso no

63 Lei n. ${ }^{\circ}$ 27/2011, de 16 de Junho, que sucedeu à Lei 8/2003, de 12 de Maio. 
aresto uniformizador é válido mesmo para os acidentes de trabalho regulados pela TNI de 1993: «1 - A expressão "se a vítima não for reconvertível em relação ao posto de trabalho" contida na alínea a) do $n .^{\circ} 5$ das Instruções Gerais da Tabela Nacional de Incapacidades por Acidente de Trabalho ou Doenças Profissionais, aprovada pelo Decreto-Lei $n .^{\circ} 341 / 93$, de 30 de Setembro, refere-se às situações em que o sinistrado, por virtude das lesões sofridas, não pode retomar o exercício das funções correspondentes ao concreto posto de trabalho que ocupava antes do acidente; 2 - Não é possivel bonificar, nos termos da alínea a) do n. 5 daquelas Instruções Gerais, o coeficiente de incapacidade geral de um profissional de futebol decorrente de acidente de trabalho, de 25 anos à data do acidente, e que retomou, após a alta, as tarefas correspondentes ao posto profissional que ocupava antes do acidente.»

\section{b. Aplicação do factor de bonificação na revisão da incapacidade}

A nossa crítica à bonificação automática da incapacidade por virtude da idade na avaliação inicial redobra quando a mesma tem lugar em sede de revisão da incapacidade, especialmente quando não se verifica qualquer agravamento.

Com efeito, assiste-se com crescente frequência à atribuição da bonificação mesmo que do exame de revisão não resulte qualquer agravamento da incapacidade, só porque o sinistrado, entretanto, completou 50 anos.

Afigura-se totalmente descabido aumentar a incapacidade por mera aplicação do factor de bonificação, tratando-se de mais um desvio interpretativo que fez escola e que importa repensar.

Todos os sinistrados tenderão a completar 50 anos de idade, pelo que é incompreensível que, logo neste domínio dos acidentes de trabalho, em que os direitos são indisponíveis, se deixe à iniciativa dos sinistrados, ao chegar à referida idade, pedir revisão para obter uma reparação adicional equivalente a metade da que tiveram até então. Seguramente que este cenário nunca esteve na mente do legislador, resultando de uma prática judicial muito discutível.

O Tribunal da Relação de Guimarães, no recentíssimo Ac. de 16/04/2015 $5^{64}$, considera mesmo que «Não pode admitir-se uma solução que implique, no que tange a este fator não ponderável, um pedido de revisão com o fito exclusivo da sua aplicação. O fator é aplicável quando à data da alta se verifica o respetivo pressuposto, sendo irrelevante o posterior decurso do tempo. Se

64 Proc. $^{0}$ 691/10.4TTBCL.P1.G1, ainda não publicado. 
a lei pretendesse que o fator fosse aplicado logo que o sinistrado atingisse os 50 anos tê-lo-ia dito, já que, dada a linha do tempo, todos os sinistrados com menos de 50 anos à data da alta, terão um dia 50 anos, salvo decesso.»

Mais problemática ainda é a situação em que do exame de revisão não resulta qualquer agravamento da incapacidade e, mesmo assim, aproveita-se para atribuir o fator 1,5 por o sinistrado ter 50 anos, idade que já tinha aquando da avaliação inicial. Faremos no ponto seguinte uma análise mais detida desta situação e das perplexidades que a mesma suscita.

Entretanto e tocando as raias do absurdo, existem já decisões de primeira instância, que esperemos não venham a ser sufragadas pelas instâncias superiores, de aceitar a aplicação do fator de bonificação mesmo quando há uma melhoria/redução da incapacidade: o sinistrado tinha uma IPP de 12\%, pede revisão alegando estar pior; contudo, verifica-se que está melhor, sendo a IPP reduzida para 10\%, só que no cômputo final, é-lhe atribuída uma IPP de $15 \%$ por aplicação daquele fator, pois completou 50 anos recentemente.

\section{Análise de um caso concreto}

No Acórdão do Tribunal da Relação de Lisboa de 30/05/2012, Proc. ${ }^{\circ}$ 468/08.7TTTVD.L1-4, propugna-se a atribuição do fator de bonificação em sede de revisão da incapacidade com base na idade superior a 50 anos e ainda que o sinistrado já tivesse essa idade aquando da avaliação inicial: «O factor de bonificação de 1,5 previsto na alinea a) da 5. Instrução Geral da TNI deve ser ponderado e aplicado desde que se mostrem verificados os requisitos legalmente previstos para o efeito, não estando a sua posterior atribuição em incidente de revisão dependente da circunstância de, no momento da fixação originária da desvalorização ao sinistrado, já o mesmo ter sido considerado e reconhecido.»

$\mathrm{O}$ aresto respeita a uma ação emergente de acidente de trabalho ocorrido em 7/04/2008, do qual resultou para o sinistrado uma incapacidade parcial permanente de $5 \%$, desde 28/11/2008.

Em 5/07/2010, o sinistrado deduziu um incidente de revisão da incapacidade, invocando agravamento das lesões sofridas no âmbito do acidente de trabalho.

Tanto no exame médico singular, como no exame por junta médica, foi atribuída ao sinistrado uma IPP de 7,5\%, exclusivamente por aplicação do fator bonificação.

O incidente de revisão foi julgado improcedente, por se ter entendido que a valoração das lesões por parte da junta médica em 7,5\% «não resultou de 
qualquer ponderação de factores objectivos de agravamento, nem de qualquer facto posterior à fixação inicial da desvalorização com relevo na capacidade de ganho do sinistrado, mas sim da aplicação do factor de bonificação previsto no ponto 5 das instruções gerais da TNI.»

Com efeito, atendendo a que o art. ${ }^{\circ} 25 .^{\circ}$ do Lei 100/97 dispõe que "Quando se verifique modificação da capacidade de ganho do sinistrado proveniente de agravamento, recidiva, recaída ou melhoria da lesão ou da doença que deu lugar a reparação, ou de intervenção clínica de aplicação de prótese ou ortótese, ou ainda de formação ou reconversão profissional, as prestações poderão ser revistas e aumentadas, reduzidas ou extintas, de harmonia com a alteração verificada», o douto tribunal de $10^{\mathrm{a}}$ instância defendeu que «a avaliação feita pela junta médica não decorreu da verificação dos pressupostos de revisão previsto na referida norma, mas tão só de uma "revisão» da decisão inicial que fixou a incapacidade permanente parcial.»

Entendeu o julgador que, não tendo sido o factor de bonificação considerado na perícia inicialmente realizada, nem valorado na decisão judicial que fixou a incapacidade do sinistrado, "aplicar, agora, o referido factor de bonificação não se traduz numa revisão da incapacidade por verificação dos pressupostos de revisão da mesma, mas sim uma revisão da decisão que fixou a incapacidade permanente parcial, sendo que o incidente previsto no art. 25. " não é o meio próprio para tal.»

Em consequência, concluiu não se ter apurado qualquer agravamento objetivo, não obstante o entendimento dos peritos, pelo que manteve a incapacidade permanente parcial anteriormente fixada.

O sinistrado, inconformado com tal decisão, interpôs recurso da mesma, vindo a ser prolatado o douto acórdão que ora se analisa, no qual se defende a aplicação da bonificação em sede de revisão da incapacidade e se considera que a sentença recorrida assenta em pressupostos discutíveis, por rejeitar que o estado clínico do sinistrado não tenha sofrido qualquer modificação objetiva, portanto, agravamento das suas lesões e, por outro lado, por considerar que o fator de bonificação previsto no n. 5 das Instruções Gerais da TNI só pode ser aplicado no momento inicial da fixação da desvalorização do sinistrado, ficando precludida a sua ponderação em fase posterior do processo.

No mesmo aresto, o Ilustre Desembargador consigna que emerge dos autos que o sinistrado ficou afetado de uma IPP de 5\%, tendo deduzido incidente de revisão 1 ano e 7 meses após a data da alta, por entender que a sua situação clínica se tinha agravado, tendo os peritos médicos que elaboraram parecer pericial sobre tal pretensão, quer em termos singulares, quer colegiais, concordado com esse agravamento e atribuindo-lhe uma IPP de $7,5 \%$, por força da aplicação do aludido factor de bonificação. 
Mais considera que "tal alteração objectiva radica-se na idade do lesado, que à data do pedido de revisão tem praticamente 56 anos» e que "quando é objectivamente examinado pela última vez, já possui 57 anos, o que, cruzado com as lesões permanentes apresentadas ao nivel do joelho esquerdo e as funções de mecânico de aviões, pelo mesmo desenvolvidas, justifica, em nossa opinião, a aplicação do factor de bonificação de 1,5, nos termos do número 5 das Instruções Gerais da nova Tabela Nacional de Incapacidades (a idade mais avançada da vítima do acidente pode realçar aspectos das lesões ou sequelas derivadas do sinistro que não tinham ressaltado anteriormente, pelo menos com a nitidez com que agora se apresentam).»

E pondera: "O tempo decorrido desde a sentença transitada e a consequente maior idade do sinistrado determinou, necessariamente, de acordo com os pareceres dos senhores peritos médicos, uma maior debilidade do estado físico daquele - que pode considerar-se equivalente a um agravamento - justificando-se, nessa medida, uma nova ponderação da aplicação do fator 1,5 em razão da idade. O perito médico do tribunal - no que é acompanhado pela Junta Médica - radica a sua posição na circunstância do sinistrado ter 53 anos à data do acidente de trabalho dos autos.»

O Ilustre Desembargador refere, finalmente, que «o facto de um dado lesado sofrer um acidente quando ainda não tem 50 anos, não invalida que no futuro, já no quadro de um dos incidentes de revisão por ele requeridos e quando já ultrapassou essa fronteira etária, veja ser-lhe aplicado o referido factor de bonificação, desde que se mostrem reunidos os demais requisitos legalmente pela Instrução Geral em questão, o mesmo tendo de ser dito quanto à não obrigatoriedade de considerar desde logo, na fixação primitiva da incapacidade, tal factor, que só se pode revelar e justificar em fase posterior do processo de revisão daquela.»

Em conformidade, julga procedente o recurso de apelação interposto pelo sinistrado, revogando a sentença recorrida e considerando o mesmo sinistrado afectado por uma IPP de 7,5\%.

Estamos perante um aresto cuja fundamentação assenta essencialmente em três pressupostos:

- na aplicabilidade da bonificação no âmbito de um incidente de revisão da incapacidade, face ao disposto no n. ${ }^{\circ} 5$ das Instruções Gerais da TNI,

- na circunstância de os exames médicos terem atribuído a bonificação e

- no decurso do tempo desde a sentença e a consequente maior idade do sinistrado, determinante de uma também maior debilidade do seu estado 
físico, equivalente a um agravamento, justificando-se, portanto, uma nova ponderação da aplicação do fator 1,5 em razão da idade.

Nenhum destes argumentos nos parece, contudo, resistir a uma análise mais aprofundada do que realmente está em causa.

Em primeiro lugar, o aresto não considera um aspeto essencial, que é a existência de uma decisão transitada em julgado ${ }^{65}$.

Depois, a incapacidade é revista e aumentada, sem que se verifique um único dos requisitos legais previstos para tal desiderato.

Passemos a analisar estes aspetos com mais detalhe.

\section{a. Ofensa do caso julgado}

A questão da aplicação do factor 1,5 não se deveria ter colocado no âmbito do incidente de revisão, uma vez que a decisão que fixou a incapacidade do sinistrado, não aplicando aquele factor, há muito que transitara em julgado.

Com efeito, o fundamento com base no qual foi atribuída aquela bonificação - idade do sinistrado superior a 50 anos - já se verificava aquando da prolação da decisão nos autos principais. Não tendo sido atribuída, vedada ficou a sua aplicação em momento ulterior.

O n. ${ }^{\circ} 1$ do artigo 580. ${ }^{\circ}$ do Código de Processo Civil dispõe que «As exceções da litispendência e do caso julgado pressupõem a repetição de uma causa; se a causa se repete estando a anterior ainda em curso, há lugar à litispendência; se a repetição se verifica depois de a primeira causa ter sido decidida por sentença que já não admite recurso ordinário, há lugar à exceção do caso julgado.» $\mathrm{O}$ n. ${ }^{\circ} 2$ acrescenta que «Tanto a exceção da litispendência como a do caso julgado têm por fim evitar que o tribunal seja colocado na alternativa de contradizer ou de reproduzir uma decisão anterior.»

Em matéria de requisitos, o artigo $581^{\circ}$ do CPC estabelece os seguintes: «1 - Repete-se a causa quando se propõe ação idêntica a outra quanto aos sujeitos, ao pedido e à causa de pedir. 2 - Há identidade de sujeitos quando as partes são as mesmas sob o ponto de vista da sua qualidade jurídica. 3 - Há identidade de pedido quando numa e noutra causa se pretende obter o mesmo efeito jurídico. 4 - Há identidade de causa de pedir quando a pretensão deduzida nas duas ações procede do mesmo facto jurídico.»

65 Nos termos do art. $^{\circ} 628^{\circ}$ do CPC, «A decisão considera-se transitada em julgado logo que não seja suscetível de recurso ordinário ou de reclamação.» 
Há igualmente que ter presente o disposto no art..$^{\circ} 619^{\circ}$ do $\mathrm{CPC}$, quanto aos efeitos da sentença transitada em julgado: «Transitada em julgado a sentença ou o despacho saneador que decida do mérito da causa, a decisão sobre a relação material controvertida fica a ter força obrigatória dentro do processo e fora dele (...)».

$\mathrm{O}$ instituto do caso julgado assume grande importância no nosso ordenamento jurídico, constituindo mesmo um dos pilares do Estado de Direito. Na lição de Antunes Varela, «A força e a autoridade atribuídas à decisão transitada em julgado, quer ela se refira à relação processual, quer sobretudo quando respeita à relação material litigada, visam evitar que a questão decidida pelo órgão jurisdicional possa ser validamente definida mais tarde, em termos diferentes, por outro ou pelo mesmo tribunal (res judicata pro veritate habetur). Trata-se de acautelar uma necessidade vital de segurança jurídica e de certeza do direito, acima da intenção de defender o prestígio da administração da justiça.

A excepção de caso julgado, assente na força e autoridade da decisão transitada, destina-se ainda a prevenir o risco de uma decisão inútil.

Desde que, havendo casos julgados contraditórios, se concede justificada prevalência à decisão que primeiro transitou em julgado (...), a instauração do segundo processo, ou a nova arguição da questão processual, representaria um gasto inútil de tempo, de esforço e de dinheiro, além de constituir um perigo para o prestígio da administração da justiça, que cumpre naturalmente prevenir.» ${ }^{66}$

O Supremo Tribunal de Justiça, por seu turno, apresenta a seguinte definição: "O caso julgado caracteriza-se essencialmente na insusceptibilidade de impugnação de uma decisão em razão do seu trânsito em julgado decorrente, por seu turno, da insusceptibilidade de interposição de recurso ordinário ou de reclamação, e o caso julgado material abrange o envolvente segmento decisório e o relativo a questões preliminares que sejam seu antecedente lógico necessário ${ }^{67}$.»

No Ac. de 10/07/2007, Proc. 97B432, o STJ sintetizou a figura do caso julgado da seguinte forma: "A violação de caso julgado pressupõe dissenso entre decisões que se situem dentro da mesma relação processual.» De destacar também o Ac. do STJ de 20/06/2012, Proc. . 241/07.0TTLSB.L1.S1: "I - A figura jurídico-processual do caso julgado pressupõe a existência de uma decisão que resolveu uma questão que entronca na relação material controvertida ou que versa sobre a relação processual, e visa evitar que essa mesma questão venha a ser validamente definida, mais tarde, em termos diferentes, pelo mesmo ou por outro tribunal. II - Na análise do caso julgado há que ter em conta duas

66 In Manual de Processo Civil, 1. ${ }^{a}$ edição, Coimbra, 1984, p. 296.

67 Ac. do STJ de 29/01/2004, Proc. $^{0}$ n. ${ }^{\circ} 03 B 3444$. 
vertentes que não se confundem: uma, que se reporta à excepção dilatória do caso julgado, cuja verificação pressupõe o confronto de duas acções - contendo uma delas decisão já transitada - e uma tríplice identidade entre ambas: de sujeitos, de causa de pedir e de pedido; a outra, respeitante à força e autoridade do caso julgado, decorrente de uma anterior decisão que haja sido proferida, designadamente no próprio processo, sobre a matéria em discussão, que se prende com a sua força vinculativa. III - A força do caso julgado não incide apenas sobre a parte decisória propriamente dita, antes se estende à decisão das questões preliminares que foram antecedente lógico, indispensável à emissão da parte dispositiva do julgado.»

Feito este enquadramento legal, doutrinal e jurisprudencial, facilmente se alcança a impossibilidade de alterar a incapacidade com base num facto que já se verificava quando foi proferida uma sentença entretanto transitada em julgado.

Vejamos: o instituto da revisão da incapacidade permite alterar a incapacidade fixada nos autos principais e decidida por sentença já transitada em julgado. Desde logo, permite que a mesma incapacidade seja aumentada, verificando-se um agravamento das sequelas incapacitantes que estiveram na origem daquela decisão.

Portanto, um facto novo e claramente superveniente ${ }^{68}$.

O que não permite é que a incapacidade seja aumentada com base num facto já existente e conhecido, designadamente pelo interessado e pelo tribunal, à data em que aquela sentença foi proferida. O incidente de revisão da incapacidade pressupõe que se verifiquem fatores de agravamento posteriores à decisão que fixou a incapacidade.

Assim, não pode uma nova sentença fixar outro valor à IPP com base em factos já conhecidos pelas partes e pelo juiz à data da sentença dos autos principais.

Uma nova IPP só é possível mercê de um agravamento real das sequelas.

Com a prolação da sentença, esgotou-se o poder jurisdicional do juiz relativamente à aplicação do factor de bonificação e, não tendo o sinistrado interposto recurso da mesma sentença, com ela se conformando, não pode, posteriormente, pugnar por aquela aplicação.

A aplicação, em momento ulterior, desse factor não constitui uma revisão da incapacidade, fundada nos pressupostos da mesma, mas sim uma revisão

68 Cfr. Ac. do Tribunal Constitucional n. ${ }^{0}$ 147/2006, de 22/02: «Assegura-se assim o direito constitucional do trabalhador à justa reparação - direito previsto no artigo $59^{\circ}, n .^{\circ} 1$, alínea f), da Constituição -, pois que a revisão da pensão permite ressarcir danos futuros não considerados no momento da fixação da pensão ou, no caso de não produção dos danos que se anteciparam, reduzir o montante da indemnização aos danos que a final se produziram.» 
da conformidade legal da decisão antes proferida e transitada em julgado. Manuela Bento Fialho refere, com propriedade, que «o incidente de revisão não pode servir de instrumento para corrigir eventuais erros de julgamento aquando da fixação inicial da incapacidade. ${ }^{69}$ "

A propósito desta problemática, o Ac. do TR de Lisboa de 22/05/2013, Proc. ${ }^{\circ}$ 183/03.8TTBRR.1L1-4, faz um enquadramento jurídico que se afigura adequado: «I - Resulta do disposto no art. 25. ${ }^{\circ}, n{ }^{\circ} 1$ do Regime Jurídico dos Acidentes de Trabalho e das Doenças Profissionais, aprovado pela Lei $n .^{\circ}$ 100/97, de 13/09, e do art. 145. ${ }^{\circ},{ }^{\circ} 6$ do Código de Processo do Trabalho, que o incidente de revisão visa a alteração das prestações a que o sinistrado tem direito em consequência de modificação na sua capacidade de ganho, proveniente dos factores indicados, e não uma alteração decorrente da reapreciação do mérito da decisão inicial, desiderato reservado aos recursos. II - Trata-se, afinal, da concretização, em matéria de prestações decorrentes de acidente de trabalho, do princípio constante do art. 671. ${ }^{\circ}$ do Código de Processo Civil, segundo o qual, em termos básicos, transitada em julgado a sentença que decida do mérito da causa, a decisão sobre a relação material controvertida fica a ter força obrigatória dentro do processo e fora dele, embora, se o réu tiver sido condenado a satisfazer prestações dependentes de circunstâncias especiais quanto à sua medida ou à sua duração, pode a sentença ser alterada desde que se modifiquem as circunstâncias que determinaram a condenação. III - Assim, se entre os momentos da prolação da sentença e da decisão de revisão ocorrer alteração da idade do sinistrado que a torne relevante para efeitos de aplicação de algum factor de bonificação, quando antes não o era, deve o mesmo ser tido em conta, assim como, na hipótese inversa, deve deixar de ser considerado.»

Também o Ac. do TR de Lisboa de 12/03/201470, com um sumário idêntico, expende o seguinte entendimento: «Assim, proferido tal despacho, ficou imediatamente esgotado o poder jurisdicional do juiz quanto à matéria em causa (art. 666. ${ }^{\circ}$, n..$^{\circ} 1$ e 2 do Código de Processo Civil de 1961, então em vigor, ex vi art. $1 .^{\circ}$ do Código de Processo do Trabalho), pelo que, caso não se conformasse com o enquadramento jurídico dos factos, deveria o sinistrado ter interposto o competente recurso, ao abrigo do disposto no art. $79 .{ }^{\circ}$, al.b) do Código de Processo do Trabalho. Não o tendo feito oportunamente, tal despacho transitou em julgado nos termos do art. $677^{\circ}$ do aludido Código de Processo Civil...»

69 Ob. cit. p. 96

70 Proc. ${ }^{\circ}$ 2197/07.0TTLSB.2.L1, não publicado. 
Está, pois, fora do âmbito do incidente processual de revisão da incapacidade a modificação ou correção da sentença inicial quanto aos efeitos da incapacidade ${ }^{71}$.

Entretanto, o Tribunal da Relação de Guimarães, veio manifestar idêntico entendimento no Ac. de 16/04/2015: «A reapreciação em sede de revisão, do cálculo da incapacidade previamente efetuado, utilizando outros critérios (podia ser este como podiam ser outros), implica necessariamente violação do caso julgado e do princípio de que proferida a sentença fica esgotado o poder jurisdicional, com dano para a legítima confiança criada na força da sentença.

Não que a incapacidade não possa ser alterada, como o demonstra o mecanismo de revisão, mas apenas nos termos da lei, ocorrendo alteração do estado de saúde do sinistrado, com agravamento, recidiva, recaída ou melhoria da lesão ou doença. É que a revisão, fundando-se em alteração posterior, não viola o caso julgado.»

E, indo mais longe, afirma: «Claro que a bonificação, e porque como referido se trata apenas de um critério de cálculo, não está em si mesma abrangida por caso julgado. Pode apesar de não aplicada por erro de julgamento na decisão inicial, ser aplicada nas posteriores revisões, verificando-se os seus pressupostos, mas deverá sê-lo sem prejuízo do caso julgado, e é, apenas sobre a parte dos danos que acresceram.»

Ou seja, a bonificação terá lugar se houver agravamento da incapacidade e aplicar-se-á somente à diferença entre a percentagem da incapacidade inicial e aquela que resultou do agravamento.

\section{b. Ausência dos requisitos de revisão da incapacidade}

Nos termos da LAT, a revisão das prestações tem lugar em várias circunstâncias. Atenta a formulação da norma, não parece que possam colocar-se dúvidas quanto a tratar-se de uma disposição taxativa, a qual prevê como fundamento para o aumento das prestações o agravamento, a recidiva $^{72}$ e a recaída ${ }^{73}$ da lesão ou doença que deu origem à reparação ${ }^{74}$.

71 Neste sentido, Ac. da Relação de Lisboa de 20/06/1984, in BMJ 345\%/442.

72 Recidiva consiste em «novo ataque de doença depois de o doente estar restabelecido de outro anterior», cfr. Dicionário Priberam da Língua Portuguesa: http://www.priberam.pt/dlpo/recidiva

73 Recaída consiste em «novo ataque de uma doença que sobrevém antes de se estar completamente curado do primeiro», cfr. Dicionário Priberam da Língua Portuguesa: http://www.priberam.pt/dlpo/recaida

74 Também NETO, ABÍlio, Código de Processo do Trabalho Anotado, 4. ${ }^{a}$ edição, 2010, p. 280, apresenta uma definição que importa reter: «0 agravamento da lesão ou doença consiste na intensificação ou aumento da gravidade do estado ou situação anterior; a recidiva traduz-se no reaparecimento de uma doença numa 
A lei não prevê qualquer outro critério para a alteração, por aumento, das prestações, que não seja o da verificação de um efetivo agravamento clínico das sequelas ${ }^{75}$. De resto, convém ter presente que o escopo do instituto da revisão da incapacidade é o de adaptar as prestações por acidente de trabalho à evolução do estado das sequelas do titular da pensão, na medida em que estas se repercutam na sua capacidade de ganho ${ }^{76}$.

Todas as demais situações previstas na norma relativa à revisão da incapacidade são fundamentadoras de uma diminuição das prestações: melhoria da lesão ou doença, intervenção clínica ou aplicação de prótese ou ortótese e formação ou reconversão profissional.

Assim, para que haja um aumento das prestações, forçoso é que seja reconhecido um agravamento clínico das sequelas emergentes do acidente.

Porém, a nossa jurisprudência tem sido recetiva a revisões aumentativas das prestações sem agravamento da incapacidade. Para lá do aresto ora em análise, a Relação do Porto, tem defendido que "O agravamento não implica, necessariamente, a diminuição da capacidade de ganho, devendo, sempre, ser aferido em função da concreta desvalorização proveniente da lesão. Pode muito bem suceder (...) que, sem diminuição da capacidade de ganho, o sinistrado veja a sua situação, no plano pessoal, mais grave ou mais pesada, diferente do que era, na altura do sinistro, e, se assim for, tal situação pode ser entendida como causa de aumento das próprias prestações.» ${ }^{77}$.

$\mathrm{E}$, noutro aresto, propugnou que «(...) embora não tenha existido um agravamento das lesões, propriamente dito, certo é que a capacidade pessoal do sinistrado para a realização das suas tarefas profissionais diminuiu, sendo de aplicar o factor de bonificação de 1,5, face à actual idade do sinistrado, pelo que o despacho impugnado é de confirmar.» ${ }^{78}$

No caso sub judice, os peritos foram unânimes em considerar que não ocorreu qualquer agravamento das lesões do sinistrado: «não se identificam critérios que, à luz da TNI, permitam afirmar agravamento», sendo isso que se afigura fundamental.

pessoa que anteriormente se tinha curado dela; a recaída ocorre quando há um agravamento dos sintomas de uma doença que estava quase curada.» (destaques nossos).

75 Ocorre-nos, contudo, a este propósito, a fundamentação recentemente dada num exame médico singular de revisão, em que é atribuído o factor 1,5 e IPATH a um sinistrado com 64 anos: «baixa escolaridade, baixas qualificações técnico-profissionais e mercado de trabalho dificil». E noutro caso, de um sinistrado com 48 anos: «bonifica-se pelo fator 1,5 porque a profissão exige esforços acrescidos e não é reconvertivel no posto de trabalho: ficou desempregado.» 0 Ac. do STJ de 28/05/2014, uniformizador de jurisprudência, assume neste âmbito inteira oportunidade.

76 Cfr. Ac. do Tribunal Constitucional n. ${ }^{\circ}$ 147/2006, de 22/02.

77 Ac. de 10/01/2011, Proc. $^{\circ}$ 267/06.0TTBGC e Ac. de 9/05/2011, Proc. ${ }^{\circ}$ 911/06.0TTBRG.2.P1, não publicados.

78 Ac. de 9/05/2011, Proc. ${ }^{\circ}$ 911/06.0TTBRG.2.P1, não publicado. 
O facto de tais peritos, do mesmo passo, terem aumentado a incapacidade do sinistrado por causa da idade, criando uma nova causa de agravamento da incapacidade, é um atropelo jurídico que se pode compreender, mas que não pode ser acolhido nem sancionado judicialmente.

A aplicação do Direito é um exclusivo do tribunal.

Ademais, os laudos de junta médica não são vinculativos para o tribunal, face ao princípio da livre apreciação da prova, consagrado no n. ${ }^{\circ} 5 \mathrm{do} \mathrm{art}^{\circ}{ }^{\circ}$ 607..$^{\circ}$ do Cód. Processo Civil ${ }^{79}$, bem como, especificamente quanto à prova pericial, o disposto no art. ${ }^{\circ} 389 .^{\circ}$ do Cód. Civil ${ }^{80}$.

A este propósito, refere Albertina Aveiro Pereira ${ }^{81}$ «Saliente-se, ainda, que os laudos da junta médica, mesmo os emitidos por unanimidade, enquanto prova pericial, não são vinculativos para o tribunal. Actua aqui o princípio da livre apreciação, baseando-se o tribunal na sua prudente convicção sobre a prova produzida, isto é, em regras da ciência e do raciocínio e em máximas da experiência».

No mesmo sentido, vide Albino Mendes Baptista ${ }^{82}$.

É pertinente citar também José Eusébio Almeida, num trecho sobre o mesmo tema: "Relativamente ao seu valor probatório, a prova pericial está (...) sujeita à livre apreciação do tribunal (artigos 389. ${ }^{\circ}$ do CC e 591. ${ }^{\circ}$ do CPC), o que significa, tão só mas relevantemente, que não existe um valor tarifado atribuído à prova, mas nunca significará que a apreciação possa ser arbitrária.

A força probatória do exame pericial encontra-se interligada com a concepção da posição do juiz expressa na máxima que o tem (ou tinha) como o "perito dos peritos". Não quer dizer que saiba tudo, mas essencialmente que está em condições, está em posição - desde logo funcional e legitimada -, de controlar o raciocínio do perito, não obstante os conhecimentos especiais deste. Naturalmente, controlar no sentido percepcional e a posteriori, nunca no sentido de o condicionar. ${ }^{83}$,

Assim, se o julgador pode afastar-se do laudo pericial em matérias estritamente clínicas, porque a ele não se encontra vinculado, forçoso é concluir que mais poderá fazê-lo perante um laudo que enverede por matérias jurídicas.

79 «0 juiz aprecia livremente as provas segundo a sua prudente convicção acerca de cada facto»

80 «A força probatória das respostas dos peritos é fixada livremente pelo tribunal.»

81 In Acidentes de trabalho (os exames médicos e a Tabela Nacional de Incapacidades), Prontuário de Direito do Trabalho n. ${ }^{0} 70,2005$, p. 123 e segts.

82 In Acidentes de Trabalho: contexto social, processo e cultura dos tribunais, Prontuário de Direito do Trabalho, n. ${ }^{\circ} 79-80-81,2008$, p. 155.

83 In Avaliação do dano e processo especial de acidentes de trabalho, Prontuário de Direito do Trabalho, $\mathrm{n}^{\circ}$ 74-75, 2006, p. 239-24. 


\section{Conclusões}

1 - O objetivo do instituto da revisão da incapacidade é a adequação da reparação à real situação clínica que para o sinistrado resultou do acidente de trabalho.

2 - O incidente respetivo visa acolher situações supervenientes e não aquelas que já se verificavam aquando da avaliação inicial e constituem objeto de decisão transitada em julgado.

3 - O prazo para o efeito deve ser um prazo razoável e, preferencialmente, adequado ao tipo de lesão, não podendo ser vitalício, sob pena de serem considerados agravamentos não respeitantes às lesões sofridas no acidente de trabalho.

4 - A possibilidade de revisão nas situações de cura sem incapacidade deve ser independente de quem seja o responsável pela reparação do acidente e limitada a um prazo mais curto, atenta a maior probabilidade de consolidação das lesões.

5 - A idade deve ser considerada casuisticamente, na avaliação de cada sinistrado.

6 - A atribuição do fator de bonificação com base na idade igual ou superior a 50 anos assenta numa ficção e abstração, em prejuízo da avaliação do impacto concreto e efetivo das sequelas na capacidade de ganho do sinistrado.

7 - A manter-se a figura da bonificação da incapacidade, a idade não deve constituir fundamento da mesma e a sua atribuição em sede de revisão da incapacidade deve ser vedada, especialmente se não houver agravamento da incapacidade.

8 - Finalmente, verificando-se agravamento da incapacidade, a aplicação do factor 1,5 com fundamento na idade deve incidir apenas sobre a diferença entre a incapacidade inicial e aquela que resultou do agravamento.

\section{Referências bibliográficas}

Alegre C. Acidentes de Trabalho e Doenças Profissionais, 2a edição, Almedina, 2000.

Almeida JE. Avaliação do dano e processo especial de acidentes de trabalho, Prontuário de Direito do Trabalho, n. ${ }^{\circ}$ 74-75, 2006, p. 229 e segts.

Ascensão JO. O Direito - Introdução e teoria geral, $2^{a}$ edição, Fundação Calouste Gulbenkian, 1980.

Baptista AM. Acidentes de Trabalho: contexto social, processo e cultura dos tribunais, Prontuário de Direito do Trabalho, n. ${ }^{\circ} 79-80-81,2008$, p. 135 e segts. 
Cardoso L. Manual de Processo do Trabalho, 3. a edição, Petrony, 2000.

Carvalho PM. Um olhar sobre o atual regime jurídico dos acidentes de trabalho: benefícios e desvantagens, Questões Laborais, Ano X, n. ${ }^{\circ}$ 21, 2003.

Corte-Real F, Tavares S, Cordeiro C et al. A Tabela Nacional de Incapacidades e o factor 1,5, Revista Portuguesa do Dano Corporal, 2004, n. ${ }^{\circ}$ 14, p 91 e segts.

Costa S. Regulamento das Custas Processuais Anotado e Comentado, 4. a edição, Almedina, 2012.

Duarte JD. Apontamentos sobre o regime vigente de reparação de danos resultantes de acidentes de trabalho. Revista Semestral do Instituto de Seguros de Portugal, Ano XVIII, n. ${ }^{\circ}$ 34, Abril de 2014.

Fialho MB. Processo de acidentes de trabalho - os incidentes - ideias para debate, Prontuário de Direito do Trabalho, n. ${ }^{\circ}$ 69, 2004, p. 79 e segts.

Magalhães T, Antunes I, Vieira DN. A avaliação do dano na pessoa no âmbito dos acidentes de trabalho e a nova Tabela Nacional de Incapacidades, Prontuário de Direito do Trabalho, n. ${ }^{\circ} 83,2009$, p. 147 e segts.

Marquez MH. Accidentes del Trabajo y Enfermedades Profesionales, Segunda Edicion, Madrid, 1953.

Mendes M, Almeida S, Botelho J. Código de Processo do Trabalho Anotado, $1^{\mathrm{a}}$ edição, Petrony, 2010.

Neto A. Código de Processo do Trabalho - Anotado, 4a edição, Ediforum, 2010.

Neto A. Acidentes de Trabalho e Doenças Profissionais - Anotado, 1a edição, Ediforum, 2011.

Pereira AA. Acidentes de trabalho (os exames médicos e a Tabela Nacional de Incapacidades), Prontuário de Direito do Trabalho, n. ${ }^{\circ}$ 70, 2005, p. 123 e segts.

Ribeiro V. Acidentes de trabalho e doenças profissionais, Petrony, 1994.

Varela A. Manual de Processo Civil, $1^{\text {a }}$ edição, Coimbra,1984. 